\title{
Distinguishing Features and Identification Criteria for K-Dioctahedral $1 M$ Micas (Illite-Aluminoceladonite and Illite-Glauconite-Celadonite Series) from Middle-Infrared Spectroscopy Data
}

\author{
Bella B. Zviagina ${ }^{1}$, Victor A. Drits ${ }^{1}$ and Olga V. Dorzhieva ${ }^{2, *}$ \\ 1 Geological Institute, Russian Academy of Science (GIN RAS), 7 Pyzhevsky per., 119017 Moscow, Russia; \\ zbella2001@yahoo.com (B.B.Z.); victor.drits@mail.ru (V.A.D.) \\ 2 Institute of Geology of Ore Deposits, Petrography, Mineralogy and Geochemistry, Russian Academy of \\ Science (IGEM RAS), 119017 Moscow, Russia \\ * Correspondence: dorzhievaov@gmail.com
}

Received: 12 December 2019; Accepted: 5 February 2020; Published: 11 February 2020

\begin{abstract}
A representative collection of K-dioctahedral $1 M$ micas ranging in composition from $(\mathrm{Mg}, \mathrm{Fe}$ )-poor illites to aluminoceladonites through Mg-rich illites (Fe-poor varieties) and from Fe-bearing, Mg-rich illites to celadonites through Fe-illites, Al-glauconites and glauconites (Fe-bearing varieties) was studied by Fourier-transform infrared (FTIR) spectroscopy in the middle-infrared region. Analysis and comparison of the relationships between the band positions and cation compositions of Fe-poor and Fe-bearing K-dioctahedral micas provided a generalized set of FTIR identification criteria that include the band positions and profiles in the regions of $\mathrm{Si}-\mathrm{O}$ bending, $\mathrm{Si}-\mathrm{O}$ stretching, and $\mathrm{OH}$-stretching vibrations. FTIR data allow unambiguous identification of illites, aluminoceladonites, and celadonites, as well as distinction between Fe-illites and illites proper, as well as between Al-glauconites and glauconites. Specifically, a sharp maximum from the AlOHMg stretching vibration at $\sim 3600 \mathrm{~cm}^{-1}$, the presence of a MgOHMg stretching vibration at $3583-3585 \mathrm{~cm}^{-1}$, as well as characteristic band positions in the Si-O bending $\left(435-439,468-472\right.$ and $\left.509-520 \mathrm{~cm}^{-1}\right)$ and stretching regions (985-1012 and 1090-1112 $\mathrm{cm}^{-1}$ ) are clearly indicative of aluminoceladonite. The distinction between Fe-illites and Al-glauconites, which have similar FTIR features, requires data on cation composition and unit-cell parameters.
\end{abstract}

Keywords: IR spectroscopy; illite; aluminoceladonite; glauconite; celadonite

\section{Introduction}

Low-temperature K-dioctahedral micas, which are abundant in various geological settings, normally occur as fine-dispersed, interlayer-deficient varieties and $1 M$ and $1 M d$ polytypes. These micas display a wide diversity of isomorphous cation substitutions in the tetrahedral and octahedral sheets and form two intersecting isomorphous series. The first series includes varieties with iron contents of $\leq 0.3$ cations per half-formula unit (p.h.f.u.), which range in composition from ( $\mathrm{Mg}, \mathrm{Fe}$ )-poor illites to aluminoceladonites through Mg-rich illites. The second series comprises Fe-bearing micas, from Fe-bearing, Mg-rich illites to celadonites through Fe-illites, Al-glauconites and glauconites [1-8]. Fe-bearing, Mg-rich illites with a total Fe content of $\sim 0.3$ cations p.h.f.u. are a common joint between the two mica series [8].

The complexity and heterogeneity of chemical composition and structural features, as well as the ambiguity in conventional nomenclature, complicate the identification of these mica varieties. Zviagina et al. [7,8] formulated a set of diagnostic criteria based on combinations of unit-cell parameters 
and cation composition variation ranges that are specific for each mica group in the two series. In particular, the distinctive features of aluminoceladonite, which has been often confused with illite, are reduced values of $c \sin \beta$ and $|c \cos \beta / a|$ parameters in combination with $b$ parameters that are smaller than those for Mg-rich illites, and slightly greater than those of $(\mathrm{Mg}, \mathrm{Fe})$-poor illites. The compositional boundary between $\left(\mathrm{Mg}, \mathrm{Fe}\right.$ )-poor illite and $\mathrm{Mg}$-rich illite occurs at $\mathrm{Si} \sim 3.4$ and $\mathrm{Mg}+\mathrm{Fe}^{2+} \sim 0.2$ cations p.h.f.u., and that between $\mathrm{Mg}$-rich illite and aluminoceladonite occurs at $\mathrm{Si} \sim 3.7$ and $\mathrm{Mg}+\mathrm{Fe}^{2+} \sim 0.6$ cations p.h.f.u. [7].

The basic compositional parameters characterizing the Fe-bearing mica varieties are the total contents of $\mathrm{Fe}$ and $\mathrm{Al}$ cations and the ratio of octahedral $\mathrm{Al}$ cation contents to the total amount of octahedral $\mathrm{Al}$ and $\mathrm{Fe}^{3+}$ cations p.h.f.u., $\mathrm{K}_{A l}$. In particular, the $\mathrm{K}_{A l}$ values are $\sim 0.9$ in Fe-bearing, Mg-rich illites, $0.65-0.75$ in Fe-illites, 0.5-0.6 in Al-glauconites, <0.5 in glauconites and (in most cases) <0.2 in celadonites [8].

In certain instances, however, the composition and unit-cell parameters variation ranges for different mica groups may overlap (e.g., Al-glauconites and glauconites) leading to complications in the identification. Moreover, simulation of powder X-ray diffraction (XRD) patterns of finely dispersed dioctahedral Fe-bearing dioctahedral micas shows that they may display phase microheterogeneity [9]. This, in turn, may lead to the presence of atypical bands in the IR spectra of micas of highly heterogeneous compositions.

Important additional diagnostic information for K-dioctahedral $1 \mathrm{M}$ mica varieties may be obtained from Fourier-transform infrared (FTIR) spectroscopy data and, in particular, from the spectra in the middle-infrared (MIR) region. The MIR spectroscopy of K-dioctahedral micas is addressed in numerous studies (e.g., [7,8,10-30] and references therein). For the most part, however, these works either deal with high-temperature $2 M_{1}$ varieties (muscovite and/or phengite) or cover a limited range of $1 M$ mica compositions (e.g., illite or celadonite). Beran [20] deliberately chose not to include illite and glauconite in his survey of the IR spectroscopic data on micas, as these minerals were "vaguely defined" and occurred "in clay-size fractions". Slonimskaya et al. [13] and Besson and Drits [17,18], who analyzed the $1 M$ K-dioctahedral micas within a wide compositional range (illites, glauconites, aluminoceladonites and celadonites), only focused on the $\mathrm{OH}$-stretching vibrations. The most recent IR studies deal with geological applications of spectroscopy data on white mica (e.g., [29,31] or with other groups of silicate minerals [32,33]).

Recently, a number of diagnostic features that include the band positions and profile in the regions of $\mathrm{Si}-\mathrm{O}$ bending, $\mathrm{Si}-\mathrm{O}$ stretching, and $\mathrm{OH}$-stretching vibrations were suggested for the illite-aluminoceladonite series [7] and the Fe-bearing K-dioctahedral micas [8]. The objectives of the present work were to (a) compare the relationships between the band positions in all the diagnostic MIR spectral regions and cation compositions of Fe-poor K-dioctahedral micas with those observed in the Fe-bearing varieties; (b) to provide, on this basis, a generalized set of reliable FTIR identification criteria to supplement the diagnostic features obtained from X-ray diffraction and chemical data. For this purpose, MIR spectroscopy data were analyzed for a representative collection of samples of diverse compositions, from $(\mathrm{Mg}, \mathrm{Fe})$-poor illites to aluminoceladonites through $\mathrm{Mg}$-rich illites and from Fe-bearing, Mg-rich illites to celadonites through Fe-illites, Al-glauconites and glauconites.

\section{Materials and Methods}

\subsection{Samples}

The 43 samples studied range in composition from $(\mathrm{Mg}, \mathrm{Fe})$-free illite to aluminoceladonite through Mg-rich illite, and from (Mg, Fe)-rich illite to celadonite through Fe-illite, Al-glauconite and glauconite (see Table 1 for the mineral identity, location, and the references to publications containing mineralogical characterizations). The chemical compositions and the corresponding crystal-chemical formulae (Table 2) for samples RM30, M422, Zempleni, KJMC3, 60/3, 602-1, 136, 68-69, PILT, BAB, TAIH, 69 and Z1 were taken from [5]; for aluminoceladonites Mal-4 and Mal-6, from [7]; for samples 37/71, 37/71a, 103 and 821-057, from [8]; and for the other samples, from the respective publications (see Table 1). 
Table 1. Sample description.

\begin{tabular}{|c|c|c|c|}
\hline$\#$ & Sample Name & Mineral Variety & Origin, Location, and Reference \\
\hline 1 & RM30 & illite, $(\mathrm{Mg}, \mathrm{Fe})$-poor & Miocene hydrothermal, Silverton Caldera, San Juan Mountains., Colorado [34] \\
\hline 2 & SG4 & illite, $(\mathrm{Mg}, \mathrm{Fe})$-poor & Miocene hydrothermally altered volcanics, Silverton Caldera, San Juan Mountains., Colorado [34] \\
\hline 3 & RM35C & illite, $(\mathrm{Mg}, \mathrm{Fe})$-poor & Miocene hydrothermally altered volcanics, Silverton Caldera, San Juan Mountains., Colorado [34] \\
\hline 4 & Fuzz-5 & illite-smectite, $\left(\mathrm{Ws}^{1}=16 \%\right)$ & Miocene hydrothermally altered volcanics, Fuzzeradvany, Hungary $[35,36]$ \\
\hline 5 & Fuzz-6 & illite-smectite, $\left(\mathrm{Ws}^{1}=16 \%\right)$ & Miocene hydrothermally altered volcanics, Fuzzeradvany, Hungary $[35,36]$ \\
\hline 6 & Zempleni & illite-smectite, $\left(\mathrm{Ws}^{1}=13 \%\right)$ & Miocene hydrothermally altered volcanics, Fuzzeradvany, Hungary $[35,36]$ \\
\hline 7 & L-2A-1 & illite, $\mathrm{Mg}$-rich & Triassic sandstone, Poland [1] \\
\hline 8 & Swe-151 & illite-smectite, $\left(\mathrm{Ws}^{1}=15 \%\right)$ & Ordovician K-bentonite, Röstånga, Sweden [37] \\
\hline 9 & IWi-1 & illite, Mg-rich & Waukesha illite, Silurian, Wisconsin, USA [38] \\
\hline 10 & 60 & illite, Mg-rich, Fe-bearing & Silty shales, Upper Riphean, South Urals, Russia [9,39] \\
\hline 11 & $60 / 3$ & illite, Mg-rich, Fe-bearing & Clayey siltstones, Upper Riphean, South Urals, Russia [5,39] \\
\hline 12 & $602-1$ & aluminoceladonite & Altered tuff in the Leeds Creek member of Twin Creek formation, Wyoming [5] \\
\hline 13 & $\mathrm{Z} 2$ & aluminoceladonite & Devonian bentonite, Barcza, Poland $[40,41]$ \\
\hline 14 & $99-3 / 5$ & aluminoceladonite & Vitric tuff in saliferous strata, Inder, Russia [42] \\
\hline 15 & Mal-4 & aluminoceladonite & Silurian K-bentonite, Podolia, Ukraine [43] \\
\hline 16 & Mal-6 & aluminoceladonite & Silurian K-bentonite, Podolia, Ukraine [43] \\
\hline 17 & 136 & aluminoceladonite & Upper-Jurassic conglomerates, Tushleg, Mongolia [44] \\
\hline 18 & $560 / 3$ & Fe-illite & Sandstones, Lower Riphean, Olenek Uplift, northern Siberia, Russia [45] \\
\hline 19 & $553 / 1$ & Fe-illite & Siltstones, Middle Riphean, Olenek Uplift, northern Siberia, Russia [46] \\
\hline 20 & 2076A & Fe-illite & Sandstones, Lower Riphean, Olenek Uplift, northern Siberia, Russia [45] \\
\hline 21 & BSH11 & Fe-illite & Siltstones, Upper Riphean, South Urals, Russia $[47,48]$ \\
\hline 22 & BSH12 & Fe-illite & Siltstones, Upper Riphean, South Urals, Russia $[47,48]$ \\
\hline 23 & KUL1 & Fe-illite & Siltstones, Upper Riphean, South Urals, Russia $[47,48]$ \\
\hline 24 & $400 / 3$ & Al-glauconite & Gravelly sandstones, Lower Riphean, Anabar Uplift, northern Siberia, Russia $[9,49]$ \\
\hline 25 & KUL2 & Al-glauconite & Siltstones, Upper Riphean, South Urals, Russia $[47,48]$ \\
\hline 26 & 551 & Al-glauconite & Gravelly sandstones, Middle Riphean, Olenek Uplift, northern Siberia, Russia $[9,46]$ \\
\hline 27 & $555 \mathrm{~A}$ & Al-glauconite & Gravelly sandstones, Middle Riphean, Olenek Uplift, northern Siberia, Russia [46] \\
\hline
\end{tabular}


Table 1. Cont.

\begin{tabular}{|c|c|c|c|}
\hline \# & Sample Name & Mineral Variety & Origin, Location, and Reference \\
\hline 28 & $402 / 1$ & glauconite & Silty shale, Lower Riphean, Anabar Uplift, Russia $[9,49]$ \\
\hline 29 & 103 & glauconite & Glauconitites, Lower Ordovician, Parila, Estonia [8] \\
\hline 30 & $37 / 71$ & glauconite & Glauconitites, Lower Ordovician, Vergale, Latvia [8] \\
\hline 31 & $37 / 71 \mathrm{~A}$ & glauconite & Siltstones, Middle Cambrian, Vergale, Latvia [8] \\
\hline 32 & PILT & glauconite & Ordovician sandstone, Latvia $[5,50,51]$ \\
\hline 33 & $68-69$ & glauconite & Leningrad region, Russia $[5,50,51]$ \\
\hline 34 & G294 & glauconite & Ordovician, Sweden [52] \\
\hline 35 & GT6-69 & glauconite & Cretaceous, Bornholm Island [52] \\
\hline 36 & GT8-66 & glauconite & Cambrian, Wyoming [52] \\
\hline 37 & 821-057 & glauconite & Greensand, Birmingham, New Jersey, Ward's Natural Science Establishment Inc., Rochester, NY [8] \\
\hline 38 & 541 & glauconite & Lower Cambrian, East Siberia, Russia [48] \\
\hline 39 & $79 / 73$ & glauconite & Zeolite-free sandstones, the Dnieper river, Ukraine [53] \\
\hline 40 & $372 / 70$ & glauconite & Zeolite-free sands, the Tyk-Butak river, Kazakhstan [53] \\
\hline 41 & TAIH & celadonite & Taiheizan, Akita Prefecture, Japan [5,54] \\
\hline 42 & 69 & celadonite & Krivoi Rog mining district, Russia $[5,55]$ \\
\hline 43 & $\mathrm{Z1}$ & celadonite & Russia $[5,56]$ \\
\hline
\end{tabular}


Table 2. Sample description.

\begin{tabular}{|c|c|c|c|c|c|c|c|c|c|c|c|c|c|}
\hline \multirow{3}{*}{$\#$} & \multirow{3}{*}{ Sample } & \multicolumn{11}{|c|}{ Cation Composition } & \multirow{3}{*}{$K_{A l^{2}}$} \\
\hline & & \multicolumn{2}{|c|}{ Tetrahedra } & \multicolumn{5}{|c|}{ Octahedra } & \multicolumn{4}{|c|}{ Interlayer } & \\
\hline & & Si & ${ }^{\mathrm{IV}} \mathrm{Al}$ & ${ }^{\mathrm{VI}} \mathrm{Al}$ & $\mathrm{Fe}^{3+}$ & $\mathrm{Fe}^{2+}$ & $\mathrm{Mg}$ & $\Sigma_{\mathrm{oct}} 1$ & $\mathbf{K}$ & $\mathrm{Ca}$ & $\mathrm{Na}$ & $\mathrm{NH}_{4}$ & \\
\hline 1 & RM30 & 3.27 & 0.73 & 1.86 & 0 & 0 & 0.14 & 2.00 & 0.80 & 0.0 & 0.01 & n.d. & 1.00 \\
\hline 2 & SG4 & 3.24 & 0.76 & 1.88 & 0.02 & n.d. & 0.1 & 2.00 & 0.79 & 0.01 & 0.05 & n.d. & 0.99 \\
\hline 3 & RM35C & 3.30 & 0.70 & 1.82 & 0.05 & n.d. & 0.13 & 2.00 & 0.73 & 0.04 & 0.02 & n.d. & 0.97 \\
\hline 4 & Fuzz-5 & 3.38 & 0.62 & 1.83 & 0.01 & n.d. & 0.14 & 1.98 & 0.68 & 0.06 & 0 & 0.01 & 0.99 \\
\hline 5 & Fuzz-6 & 3.42 & 0.58 & 1.75 & 0.02 & n.d. & 0.23 & 2.00 & 0.70 & 0.05 & 0 & 0.01 & 0.99 \\
\hline 6 & Zempleni & 3.43 & 0.57 & 1.78 & 0.01 & n.d. & 0.22 & 2.01 & 0.66 & 0.03 & 0.03 & n.d. & 0.99 \\
\hline 7 & L-2A-1 & 3.45 & 0.55 & 1.57 & 0.13 & n.d. & 0.28 & 1.98 & 0.78 & 0.02 & 0.06 & n.d. & 0.92 \\
\hline 8 & Swe-151 & 3.49 & 0.51 & 1.68 & 0.04 & n.d. & 0.27 & 1.99 & 0.58 & 0.06 & 0.01 & 0.06 & 0.99 \\
\hline 9 & IWi-1 & 3.56 & 0.44 & 1.44 & 0.14 & n.d. & 0.39 & 1.97 & 0.72 & 0 & 0.16 & n.d. & 0.91 \\
\hline 10 & 60 & 3.63 & 0.37 & 1.32 & 0.13 & 0.16 & 0.46 & 2.07 & 0.77 & 0 & 0.01 & n.d. & 0.91 \\
\hline 11 & $60 / 3$ & 3.65 & 0.35 & 1.38 & 0.13 & 0.15 & 0.40 & 2.06 & 0.75 & 0.02 & 0.01 & n.d. & 0.91 \\
\hline 12 & $602-1$ & 3.71 & 0.29 & 1.39 & 0.04 & 0.09 & 0.51 & 2.03 & 0.75 & 0.01 & 0.03 & n.d. & 0.97 \\
\hline 13 & $\mathrm{Z} 2$ & 3.81 & 0.19 & 1.19 & 0.06 & 0.17 & 0.57 & 1.99 & 0.86 & 0.04 & 0 & n.d. & 0.95 \\
\hline 14 & $99-3 / 5$ & 3.78 & 0.22 & 1.28 & 0.11 & 0.06 & 0.59 & 2.04 & 0.65 & 0.05 & 0.01 & n.d. & 0.92 \\
\hline 15 & Mal-4 & 3.84 & 0.16 & 1.33 & 0.09 & n.d. & 0.55 & 1.97 & 0.65 & 0.05 & 0.01 & 0.05 & 0.93 \\
\hline 16 & Mal-6 & 3.86 & 0.14 & 1.29 & 0.09 & n.d. & 0.60 & 1.98 & 0.67 & 0.04 & 0.01 & 0.05 & 0.93 \\
\hline 17 & 136 & 4.00 & 0 & 1.08 & 0.13 & 0.19 & 0.60 & 2.00 & 0.78 & 0 & 0.01 & n.d. & 0.89 \\
\hline 18 & $560 / 3$ & 3.62 & 0.38 & 1.12 & 0.37 & 0.20 & 0.32 & 2.01 & 0.80 & 0 & 0.05 & n.d. & 0.75 \\
\hline 19 & $553 / 1$ & 3.57 & 0.43 & 1.13 & 0.50 & 0.19 & 0.19 & 2.01 & 0.69 & 0.04 & 0.02 & n.d. & 0.69 \\
\hline 20 & $2076 \mathrm{~A}$ & 3.68 & 0.32 & 1.03 & 0.55 & 0.09 & 0.34 & 2.01 & 0.69 & 0.01 & 0.01 & n.d. & 0.65 \\
\hline 21 & BSH11 & 3.71 & 0.29 & 1.06 & 0.36 & 0.23 & 0.39 & 2.04 & 0.74 & 0.02 & 0 & n.d. & 0.75 \\
\hline 22 & BSH12 & 3.73 & 0.27 & 0.88 & 0.37 & 0.37 & 0.47 & 2.09 & 0.78 & 0.02 & 0 & n.d. & 0.70 \\
\hline 23 & KUL1 & 3.71 & 0.29 & 0.99 & 0.43 & 0.27 & 0.37 & 2.06 & 0.78 & 0.01 & 0 & n.d. & 0.70 \\
\hline 24 & $400 / 3$ & 3.63 & 0.37 & 0.91 & 0.60 & 0.20 & 0.34 & 2.05 & 0.76 & 0.01 & 0.02 & n.a & 0.60 \\
\hline 25 & KUL2 & 3.72 & 0.28 & 0.86 & 0.54 & 0.25 & 0.39 & 2.04 & 0.76 & 0.02 & 0 & n.d. & 0.61 \\
\hline 26 & 551 & 3.67 & 0.33 & 0.85 & 0.77 & 0.15 & 0.22 & 1.99 & 0.77 & 0.01 & 0.02 & n.d. & 0.52 \\
\hline 27 & $555 \mathrm{~A}$ & 3.63 & 0.37 & 0.77 & 0.76 & 0.16 & 0.34 & 2.03 & 0.73 & 0.01 & 0.02 & n.d. & 0.50 \\
\hline 28 & $402 / 1$ & 3.80 & 0.20 & 0.52 & 0.78 & 0.28 & 0.47 & 2.05 & 0.74 & 0 & 0.04 & n.d. & 0.40 \\
\hline 29 & 103 & 3.67 & 0.33 & 0.37 & 1.15 & 0.11 & 0.40 & 2.03 & 0.74 & 0 & 0 & n.d. & 0.24 \\
\hline 30 & $37 / 71$ & 3.57 & 0.43 & 0.38 & 1.15 & 0.10 & 0.45 & 2.08 & 0.72 & 0.01 & 0.02 & n.d. & 0.25 \\
\hline
\end{tabular}


Table 2. Cont.

\begin{tabular}{|c|c|c|c|c|c|c|c|c|c|c|c|c|c|}
\hline \multirow{3}{*}{$\#$} & \multirow{3}{*}{ Sample } & \multicolumn{11}{|c|}{ Cation Composition } & \multirow{3}{*}{$K_{A l^{2}}^{2}$} \\
\hline & & \multicolumn{2}{|c|}{ Tetrahedra } & \multicolumn{5}{|c|}{ Octahedra } & \multicolumn{4}{|c|}{ Interlayer } & \\
\hline & & Si & ${ }^{\mathrm{IV}} \mathrm{Al}$ & $\mathrm{VI}^{\mathrm{VI}} \mathrm{Al}$ & $\mathrm{Fe}^{3+}$ & $\mathrm{Fe}^{2+}$ & Mg & $\Sigma_{\text {oct }} 1$ & $\mathbf{K}$ & $\mathrm{Ca}$ & $\mathrm{Na}$ & $\mathrm{NH}_{4}$ & \\
\hline 31 & $37 / 71 \mathrm{~A}$ & 3.56 & 0.44 & 0.64 & 0.96 & 0.19 & 0.28 & 2.07 & 0.68 & 0 & 0.01 & n.d. & 0.40 \\
\hline 32 & PILT & 3.73 & 0.27 & 0.44 & 0.92 & 0.22 & 0.47 & 2.05 & 0.77 & 0 & 0.03 & n.d. & 0.32 \\
\hline 33 & $68-69$ & 3.73 & 0.27 & 0.43 & 0.92 & 0.30 & 0.39 & 2.04 & 0.80 & 0.01 & 0.03 & n.d. & 0.32 \\
\hline 34 & G294 & 3.72 & 0.28 & 0.74 & 0.82 & n.d. & 0.40 & 1.96 & 0.67 & 0.06 & 0.02 & n.d. & 0.47 \\
\hline 35 & GT6-69 & 3.78 & 0.22 & 0.57 & 0.95 & n.d. & 0.47 & 1.99 & 0.69 & 0.01 & 0 & n.d. & 0.38 \\
\hline 36 & GT8-66 & 3.60 & 0.40 & 0.37 & 1.26 & n.d. & 0.32 & 1.95 & 0.72 & 0 & 0.12 & n.d. & 0.23 \\
\hline 37 & $821-057$ & 3.74 & 0.26 & 0.33 & 1.23 & n.d. & 0.41 & 1.97 & 0.68 & 0.03 & 0.01 & n.d. & 0.22 \\
\hline 38 & 541 & 3.53 & 0.47 & 0.68 & 0.72 & 0.29 & 0.40 & 2.09 & 0.78 & 0.06 & 0.01 & n.d. & 0.49 \\
\hline 39 & $79 / 73$ & 3.65 & 0.35 & 0.37 & 1.16 & 0.05 & 0.44 & 2.02 & 0.67 & 0.06 & 0.01 & n.d. & 0.27 \\
\hline 49 & $372 / 70$ & 3.68 & 0.32 & 0.51 & 1.01 & 0.08 & 0.40 & 2.00 & 0.65 & 0.06 & 0.02 & n.d. & 0.27 \\
\hline 41 & TAIH & 3.72 & 0.28 & 0.16 & 1.07 & 0.10 & 0.71 & 2.04 & 0.82 & 0 & 0.18 & n.d. & 0.13 \\
\hline 42 & 69 & 3.94 & 0.06 & 0.06 & 1.15 & 0.36 & 0.41 & 1.98 & 0.83 & 0.03 & 0.01 & n.d. & 0.05 \\
\hline 43 & $\mathrm{Z1}$ & 3.96 & 0.04 & 0.05 & 0.96 & 0.26 & 0.73 & 2.00 & 0.89 & 0 & 0.07 & n.d. & 0.05 \\
\hline
\end{tabular}

The contents of $\mathrm{TiO}_{2}$ were excluded from the calculation of the crystal-chemical formulae. Samples 2-9, 15-16, and 34-37 were not analyzed for Fe oxidation state, and the formulae were calculated assuming all $\mathrm{Fe}$ as $\mathrm{Fe}^{3+} ; “ \mathrm{n} \cdot \mathrm{d}^{\prime \prime}=$ not determined. ${ }^{1} \Sigma_{\mathrm{oct}}=\mathrm{Al}+\mathrm{Mg}+\mathrm{Fe}^{2+}+\mathrm{Fe}^{3+} ;{ }^{2} \mathrm{~K}_{A l}={ }^{\mathrm{VI}} \mathrm{Al}\left({ }^{\mathrm{VI}} \mathrm{Al}+\mathrm{Fe}^{3+}\right)$. 


\subsection{FTIR Spectroscopy}

\subsubsection{Experiment}

The absorption spectra of samples RM30, RM35C, SG4, Zempleni, L-2A-1, 60/3, 602-1, Seifert, 99-3/5, 136, BSH11, KUL1, 68/69, PILT, 821-057, K294, GT 7-66, GT 8-69, 79/73, 372/70, TAIH, 69 and Z1 (Supplementary materials Figure S1) were recorded with a Nicolet ESP-260 FTIR spectrometer (Thermo Fisher Scientific, Waltham, MA, USA), and for samples Fuzz-5, Fuzz-6, Mal-4, Mal-6, 60, 560/3, 553/1, 2076, BSh12, KUL2, 400/3, 402/1, 551, 555A, 103, 37/71, 37/71A and 541 (Supplementary materials Figure S1), the IR spectra were obtained using a Bruker VERTEX 80v FTIR spectrometer (Bruker Optics, Ettlingen, Germany). Both spectrometers were equipped with an IR source, a KBr beam splitter and a DTGS KBr detector. For each sample, 128 (Nicolet) and 256 (Bruker) scans were recorded (on the Bruker spectrometer, in vacuum) in the MIR region $\left(400-4000 \mathrm{~cm}^{-1}\right)$ with a resolution of $4 \mathrm{~cm}^{-1}$.

All the samples were prepared using the $\mathrm{KBr}$ pressed-disc technique. To obtain a $\mathrm{KBr}$ pellet, 0.5 $\mathrm{mg}$ of sample was dispersed in $200 \mathrm{mg}$ of $\mathrm{KBr}$, the resulting mixture was placed in a $13 \mathrm{~mm}$ pellet die and pressed under vacuum for $15 \mathrm{~min}$. The pellet was then placed into a glass desiccant box with $\mathrm{CaCl}_{2}$ and heated in a furnace at $105-150{ }^{\circ} \mathrm{C}$ for at least $20 \mathrm{~h}$.

The IR absorbance conversion was made automatically with the Nicolet ${ }^{\circledR}$ Omnic Software Version 5.0 and the OPUS 7.0 software package (Bruker Ltd.).

\subsubsection{Spectra Decomposition and Curve-Fitting}

The $\mathrm{OH}$-stretching regions of selected spectra were decomposed and fitted using the Galactic PeakSolveTM program. The baseline correction for the $3000-4000 \mathrm{~cm}^{-1}$ region was made using the linear function, as it provided better fitting results than the Concave Rubberband method. The second derivative method was used for initial estimation of the band positions. Although theoretically the vibrational bands should be Lorentzian, various instrumental and/or compositional factors may affect their shape leading to a Gaussian or mixed Gaussian-Lorentzian distribution [57,58]. Indeed, a variety of band shapes has been used previously for the decomposition of the $\mathrm{OH}$-bending and OH-stretching regions of dioctahedral 2:1 phyllosilicates: Lorentzian [17,18,59], Gaussian [60,61] and mixed Gaussian-Lorentzian [62,63]. For the FTIR spectra under study, the best fitting results were obtained assuming a Lorentzian peak shape for each $\mathrm{OH}$ band in celadonites, a mixed Gaussian-Lorentzian shape for aluminoceladonites and Al-glauconites, and a Gaussian peak shape for illites, Fe-illites, and glauconites (Supplementary materials Table S1). The variable parameters were position, width at half-height and the intensity of each component. The complex wide absorption band of the residual water was included in the fitted spectrum as two broad maxima around 3200 and $3420 \mathrm{~cm}^{-1}$. The quality of spectra decomposition was estimated by the minimization function, $\chi^{2}$, the correlation coefficient, $\mathrm{R}^{2}$, and the agreement between cation compositions obtained from FTIR data and the crystal-chemical formulae.

\section{Results and Discussion}

The positions of the absorption bands in the FTIR spectra of the samples in the MIR region were assigned to specific vibration modes (Tables 3 and 4) following the interpretations of $[12,14-18,22,26,64]$. The FTIR spectra of all the samples are typical for dioctahedral micas. The following FTIR regions were analyzed: the Si-O bending $\left(600-400 \mathrm{~cm}^{-1}\right)$, Si-O stretching $\left(\sim 1200-700 \mathrm{~cm}^{-1}\right)$ and OH-stretching $\left(3700-3500 \mathrm{~cm}^{-1}\right)$ regions, as well as the $950-600 \mathrm{~cm}^{-1}$ region, which contains, along with the $\mathrm{OH}-\mathrm{bending}$ bands, other types of vibrations and bands corresponding to admixtures (see below). Most of the diagnostic information for all the groups of mica varieties is provided by the three characteristic $\mathrm{Si}-\mathrm{O}$ bending bands, the most intense absorption band(s) due to the $\mathrm{Si}-\mathrm{O}$ stretching vibrations, and the positions and profile of the $\mathrm{OH}$-stretching bands (Figure 1, Table 3). 
Table 3. Characteristic band positions $\left(\mathrm{cm}^{-1}\right)$ in the $\mathrm{Si}-\mathrm{O}$ bending, $\mathrm{Si}-\mathrm{O}$ stretching, and $\mathrm{OH}$-stretching regions in the FTIR spectra of $\mathrm{K}$-dioctahedral $1 M$ micas.

\begin{tabular}{|c|c|c|c|c|c|c|c|c|c|c|c|c|}
\hline \# & Sample & Si-O Bend & Si-O-Si Bend & Si-O-Si Bend (Additional) & Si-O-Fe Bend & Si-O-Al Bend & Si-O Stretch & Si-Oap Stretch & \multicolumn{4}{|c|}{ OH-Stretch, Visually Discernable Absorption Maxima } \\
\hline 1 & RM30 & 414 & 477 & - & - & 534 & 1023 & 1066sh & - & - & - & 3629 \\
\hline 2 & SG4 & 414 & 477 & - & - & 535 & 1024 & $1067 \mathrm{sh}$ & - & - & - & 3627 \\
\hline 3 & $\begin{array}{c}\text { SG4 } \\
\text { RM35C }\end{array}$ & 414 & 476 & - & - & 533 & 1023 & $\begin{array}{l}100 / \text { sn } \\
108 \mathrm{sh}\end{array}$ & - & - & - & 3629 \\
\hline 4 & Fuzz-5 & 418 & 474 & - & - & 534 & 1024 & 1090 & - & - & - & 3630 \\
\hline 5 & Fuzz-6 & 425 & 471 & - & - & 525 & 1027 & $1082 \mathrm{sh}$ & - & - & - & 3625 \\
\hline 6 & Zempleni & 423 & 474 & - & - & 529 & 1027 & 1070sh & - & - & - & 3624 \\
\hline 7 & L-2A-1 & 419 & 472 & - & - & 523 & 1021 & 1075 & - & - & - & 3618 \\
\hline 8 & Swe-151 & 422 & 472 & - & - & 524 & 1019 & $1088 \mathrm{sh}$ & - & - & - & 3626 \\
\hline 9 & IWi-1 & 424 & 472 & - & - & 520 & 1015 & 1090 & - & - & - & 3617 \\
\hline 10 & 60 & 434 & 471 & - & - & 519 & 1008 & 1089 & - & - & - & 3606 \\
\hline 11 & $60 / 3$ & 435 & 470 & - & - & 519 & 1010 & 1084 & - & - & - & 3607 \\
\hline 12 & $602-1$ & 436 & 470 & - & - & 518 & 1007 & 1091 & & & & 3601 \\
\hline 13 & $\mathrm{Z} 2$ & 437 & 472 & - & - & 512 & 989 & 1090 & 3538 & 3559 & 3583 & 3603 \\
\hline 14 & $99-3 / 5$ & 435 & 470 & - & - & 520 & 1012 & 1098 & - & - & - & 3605 \\
\hline 15 & Mal-4 & 435 & 470 & - & - & 518 & 1010 & 1090 & - & - & - & 3606 \\
\hline 16 & Mal-6 & 435 & 470 & - & - & 518 & 1006 & 1091 & & & & 3603 \\
\hline 17 & 136 & 439 & 468 & - & - & 509 & 985 & 1112 & 3541 & 3562 & 3583 & 3603 \\
\hline 18 & $560 / 3$ & 436 & 471 & - & - & 518 & 1008 & 1084 & 3528 & - & - & 3612 \\
\hline $\begin{array}{l}18 \\
19\end{array}$ & $553 / 1$ & 434 & 471 & $451 \mathrm{sh}$ & & 526 & 1017 & $1083 \mathrm{sh}$ & 3534 & - & - & 3624 \\
\hline 20 & 2076 & 437 & 469 & 453 & $486 \mathrm{sh}$ & 517 & 1000 & 1085 & 3530 & 3554 & - & 3607 \\
\hline 21 & BSh11 & 437 & $\begin{array}{l}407 \\
467\end{array}$ & $450 \mathrm{sh}$ & $496^{*}$ & 517 & 1004 & 1084 & 3536 & 3558 & 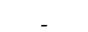 & 3605 \\
\hline 22 & BSh12 & 437 & 467 & - & - & 515 & 1007 & 1084 & 3534 & 3555sh & $3582 \mathrm{sh}$ & 3602 \\
\hline 23 & KUL1 & 438 & 467 & 454sh & 490 & 514 & 998 & 1087 & 3533 & 3554 & 3584 & 3602 \\
\hline 24 & $400 / 3$ & 438 & 468 & 455sh & 484sh & 515sh & 994 & 1079 & 3532 & 3555sh & - & 3603 \\
\hline 25 & KUL2 & 438 & 469 & $454 \mathrm{sh}$ & 484sh & 518 & 1012 & 1081sh & 3533 & 3555sh & - & $3602,3618 \mathrm{sh}$ \\
\hline 26 & 551 & 434 & 465 & 454 & 486sh & $514 \mathrm{sh}$ & 1006 & $1084 \mathrm{sh}$ & 3533 & 3560sh & - & 3610 \\
\hline 27 & $555 \mathrm{~A}$ & 437 & 469 & 455 & 486sh & $518 \mathrm{sh}$ & 1002 & 1080sh & 3532 & 3560sh & - & 3609 \\
\hline 28 & $402 / 1$ & 438 & 453 & 467 & 483sh & - & 990 & 1082 & 3533 & $3555 \mathrm{sh}$ & - & $3603^{*}$ \\
\hline 29 & 103 & 434 & 455 & - & 491 & - & 991 & 1074 & 3537 & 3559 & - & $3602 \mathrm{sh}$ \\
\hline 30 & $\begin{array}{l}103 \\
37 / 71\end{array}$ & $\begin{array}{l}454 \\
434\end{array}$ & $\begin{array}{l}450 \\
456\end{array}$ & - & $\begin{array}{l}491 \\
491\end{array}$ & - & 995 & $\begin{array}{l}1074 \\
1072\end{array}$ & 3535 & $\begin{array}{l}3539 \\
3561\end{array}$ & - & $\begin{array}{l}36003 \mathrm{sh} \\
3603 \mathrm{~s}\end{array}$ \\
\hline 31 & $37 / 71 \mathrm{~A}$ & 435 & 457 & - & 487 & - & 1001 & $1079 \mathrm{sh}$ & 3538 & - & $3581 \mathrm{sh}$ & $3603 \mathrm{sh}$ \\
\hline 32 & PILT & 439 & 459 & - & 494 & - & 1010 & 1081sh & - & 3550 & - & \\
\hline 33 & $68 / 69$ & 437 & 457 & - & 494 & - & 1013 & $1082 \mathrm{sh}$ & \multicolumn{2}{|c|}{$\begin{array}{c}3550 \\
(3530+3542+3567)(2 \text { nd drv })\end{array}$} & - & \\
\hline 34 & G294 & 435 & 463 & - & 499sh & - & 995 & 1082 & $\begin{array}{c}(3030+3042 \\
3534\end{array}$ & $\begin{array}{l}3558 \\
3558 \text { (n) }\end{array}$ & & 3604 \\
\hline 35 & GT6-69 & 437 & 458 & - & 492 & - & 987 & 1084 & 3536 & 3559 & 3583sh & 3603 \\
\hline 36 & GT8-66 & 434 & 454 & - & 489 & - & 992 & 1075 & 3536 & $3564 \mathrm{sh}$ & & $3604 \mathrm{sh}$ \\
\hline 37 & $821-057$ & $\begin{array}{l}454 \\
438\end{array}$ & $\begin{array}{l}454 \\
456\end{array}$ & - & $\begin{array}{l}409 \\
492\end{array}$ & - & 992 & 1078 & $\begin{array}{l}3500 \\
3538\end{array}$ & 3568 & & 3602 \\
\hline 38 & 541 & 438 & 458 & - & 483 & $526 \mathrm{sh}$ & 1000 & 1072 & 3533 & 3558 & - & 3621 \\
\hline 39 & $79 / 73$ & 439 & 461 & - & 496 & - & 1016 & 1099sh & \multirow{2}{*}{\multicolumn{2}{|c|}{$\begin{array}{c}3553 \\
(3537+3558)(2 \text { nd drv }) \\
3550\end{array}$}} & - & $3601 \mathrm{sh}$ \\
\hline 40 & $372 / 70$ & 440 & 460 & - & 496 & - & 1014 & 1101 & & & - & $3614 \mathrm{sh}$ \\
\hline 41 & TAIH & 439 & 459 & - & 493 & - & 978 & 1090 & 3532 & 3556 & - & 3601 \\
\hline 42 & 69 & 440 & 457 & - & 491 & - & 975, 995sh & $1072,1100 \mathrm{sh}$ & 3533 & $3555 \mathrm{sh}$ & - & 3603 (2nd drv) \\
\hline 43 & $\mathrm{Z} 1$ & n.d. & n.d. & - & n.d. & - & 957,978 & 1074,1113 & 3533 & 3556 & - & 3602 \\
\hline
\end{tabular}

*—weak, 2nd drv—determined from the second derivative, sh—shoulder, n.d.—not determined. 
Table 4. Positions $\left(\mathrm{cm}^{-1}\right)$ of absorption bands of the mica structure and common admixtures in the 950-600 $\mathrm{cm}^{-1}$ region.

\begin{tabular}{|c|c|c|c|c|c|c|c|c|c|}
\hline \# & Sample & $\begin{array}{l}\text { Coupled Al-O and Si-O } \\
\text { out-of-Plane of Smectite }\end{array}$ & $\begin{array}{l}\text { Si-O; Fe-O out-of-Plane; } \\
\text { Quartz; Carbonates }\end{array}$ & $\begin{array}{l}\text { Al-O-Si in-Plane; } \\
\delta\left(\mathrm{Fe}^{2+} \mathrm{OHFe}^{3+}\right) ?\end{array}$ & $\begin{array}{c}\mathrm{Al}-\mathrm{O}-\mathrm{Al} ; \delta\left(\mathrm{Fe}^{3+} \mathrm{OHMg}\right) ; \\
\delta\left(\mathrm{Fe}^{2+} \mathrm{OHFe}^{3+}\right) ; \text { Silica/Quartz; Goethite }\end{array}$ & $\delta\left(\mathrm{Fe}^{3+} \mathrm{OHFe}^{3+}\right)$ & $\begin{array}{c}\delta(\mathrm{AlOHMg}) / \mathrm{Al}-\mathrm{O} \text { out of } \\
\text { Plane/ Second } \delta\left(\mathrm{Fe}^{3+} \mathrm{OHFe}^{3+}\right)\end{array}$ & $\begin{array}{l}\mathrm{Al}-\mathrm{O}-\mathrm{Al} ; \delta\left(\mathrm{AlOHFe}^{3+}\right) ; \\
\text { Goethite }\end{array}$ & $\delta$ (AlOHAl) \\
\hline 1 & RM30 & 623sh & 697 & 756 & 806 & - & 830 & $876 \mathrm{sh}$ & $(912,932) * * *$ \\
\hline 2 & SG4 & $626 \mathrm{sh}$ & 695 & 756 & 804 & - & 831 & $876 \mathrm{sh}$ & $(917,933) * * *$ \\
\hline 3 & RM35C & $624 \mathrm{sh}$ & 695 & 756 & 803 & - & 826 & $876 \mathrm{sh}$ & $(918,934) * * *$ \\
\hline 4 & Fuzz-5 & $626 \mathrm{sh}$ & 694 & 755 & 803sh & - & 826 & $876 \mathrm{sh}$ & $(913,932)^{* * *}$ \\
\hline 5 & Fuzz-6 & 618 & 699 & 754 & $799 *$ & - & 823,848 & $882 \mathrm{sh}$ & 913 \\
\hline 6 & Zempleni & 618 & 695 & 755 & 804 & - & 826 & $882 *$ & 917 \\
\hline 7 & L-2A-1 & 615sh & 687 & 752 & 801sh & - & 827 & $871^{* *}$ & 913 \\
\hline 8 & Swe-151 & $620 \mathrm{sh}$ & 693 & 753 & $782,799 *$ & - & 832 & 876 & 912 \\
\hline 9 & IWi-1 & 628 & 690sh & 753 & $795 *$ & - & 834 & 870 & 911 \\
\hline 10 & 60 & $627^{* *}$ & 682 & 748 & 803 & - & 834 & 864 & 912 \\
\hline 11 & $60 / 3$ & 635 & 681 & 750 & 790 & - & 831 & 868 & 909 \\
\hline 12 & $602-1$ & - & 686 & 753 & $794 *$ & - & 835 & 877 & 912 \\
\hline 13 & $\mathrm{Z2}$ & - & 686 & 750 & $780,800 *$ & - & 835 & 874 & 912sh \\
\hline 14 & $99-3 / 5$ & 623 & 688 & 752 ** & 780,800 ** & - & 838 & $873 *$ & 914 \\
\hline 15 & Mal-4 & 625 & 685 & 752 & 802sh & - & 839 & $875 \mathrm{sh}$ & 912 \\
\hline 16 & Mal-6 & $626^{* *}$ & 686 & 752 & $787 *$ & - & 836 & $876^{*}$ & 913 \\
\hline 17 & 136 & - & 687 & 749 & 780,799 & - & 835 & 875sh & 911sh \\
\hline 18 & $560 / 3$ & - & 683 & 753 & $\sim 799 \mathrm{sh}$ & 829 & 829 & 862,878 & 915 \\
\hline 19 & $553 / 1$ & 620 & 683 & 753 & $\sim 800 \mathrm{sh}$ & 824 & 824 & 870sh & 913sh \\
\hline 20 & $2076 \mathrm{~A}$ & - & 682 & 754 & 795sh & - & 830 & 864,878 & 915sh \\
\hline 21 & BSH11 & - & 680 & 754sh & $798 s h$ & - & 831 & 860,874 & 910 \\
\hline $\begin{array}{l}21 \\
22\end{array}$ & $\begin{array}{l}\text { DSH1211 } \\
\text { BSH }\end{array}$ & 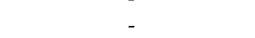 & $\begin{array}{l}\text { ovo } \\
691\end{array}$ & 751sh & $\begin{array}{c}1 \\
780,799\end{array}$ & 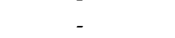 & $\begin{array}{l}801 \\
833\end{array}$ & $\begin{array}{l}877 \mathrm{sh} \\
\end{array}$ & 914sh \\
\hline 23 & KUL1 & 625 & 681 & 752sh & $\sim 797 \mathrm{sh}$ & - & 830 & $(860,876)$ & 910sh \\
\hline 24 & $400 / 3$ & & 682 & 754sh & 797sh & 823 & 838 & 863sh & 911sh \\
\hline 25 & KUL2 & 625 & 683 & 752sh & 801 & 824 & 824 & 870sh & 912sh \\
\hline 26 & 551 & 625 & 681 & 760sh & 796sh & 819 & 839 & $865 \mathrm{sh}$ * & $910 \mathrm{sh}$ * \\
\hline 27 & $555 \mathrm{~A}$ & - & 682 & 759sh & 798sh & 822 & 841 & $865 \mathrm{sh} *$ & $911 \mathrm{sh} *$ \\
\hline 28 & $402 / 1$ & & 683 & & 797sh & 821sh & 838 & $(861,878)$ & 907 \\
\hline 29 & 103 & 622 & 676 & 760sh & 798 & 815 & 835sh & 864sh & 907 \\
\hline 30 & $37 / 71$ & $620^{* * *}$ & 678 & 764sh & 800 & 812 & $837 \mathrm{sh}$ & $865 \mathrm{sh}$ & $905 \mathrm{sh}$ \\
\hline 31 & $37 / 71 \mathrm{~A}$ & 624 & 681 & 753sh & $780,797 * *$ & 820 & 834 * & 871sh & 911sh \\
\hline 32 & PILT & $620 * *$ & $670,698 \mathrm{sh}$ & 760 & 798 & 815 & 836 & $872 \mathrm{sh}$ & 907 \\
\hline 33 & $68-69$ & - & $677,696 \mathrm{srp}$ & $762 \mathrm{sh}$ & $778^{* *}, 796$ & 815 & 834 & 863sh & 907 \\
\hline 34 & G294 & - & 683 & 760sh & 804sh & $817^{*}$ & 836 & 861sh & 911sh \\
\hline 35 & GT6-69 & $620 * *$ & 681 & $762 \mathrm{sh}$ & 776sh, 801 & 811 & 835 & 861sh & $907 \mathrm{sh} *$ \\
\hline 36 & GT8-66 & 620 & 680 & 760sh & 776 & 814 & 836 & 864sh & 907sh \\
\hline 37 & $821-057$ & - & 676 & & 779,800 & $815 \mathrm{sh}$ & $835 \mathrm{sh}$ & $866 \mathrm{sh}$ & 908 \\
\hline 38 & 541 & 625 & 684 & 755 & 780,800 & 812 & 834 & 870sh & $913 \mathrm{sh}$ \\
\hline 39 & $79 / 73$ & - & $678,698 \mathrm{srp}$ & 760 & 797 & $817^{*}$ & $838^{*}$ & 870sh & $907 \mathrm{sh}$ \\
\hline 40 & $372 / 70$ & 623 ** & $677,698 \mathrm{srp}$ & 760 & - & 816 & 834 * & $867 \mathrm{sh} *$ & 910sh \\
\hline 41 & TAIH & 618 & $681,695 \mathrm{srp}$ & 760 * & 799 & 821 & 840 & $(873,888) *$ & $908 \mathrm{sh}$ \\
\hline 42 & 69 & - & 678, 697srp & 757sh & 779sh, 797 & 818sh & 843 & 872sh & - \\
\hline 43 & $\mathrm{Z} 1$ & - & 684 & $746^{*}$ & 800 & 822 & 843 ** & & - \\
\hline
\end{tabular}

visually distinct band. 

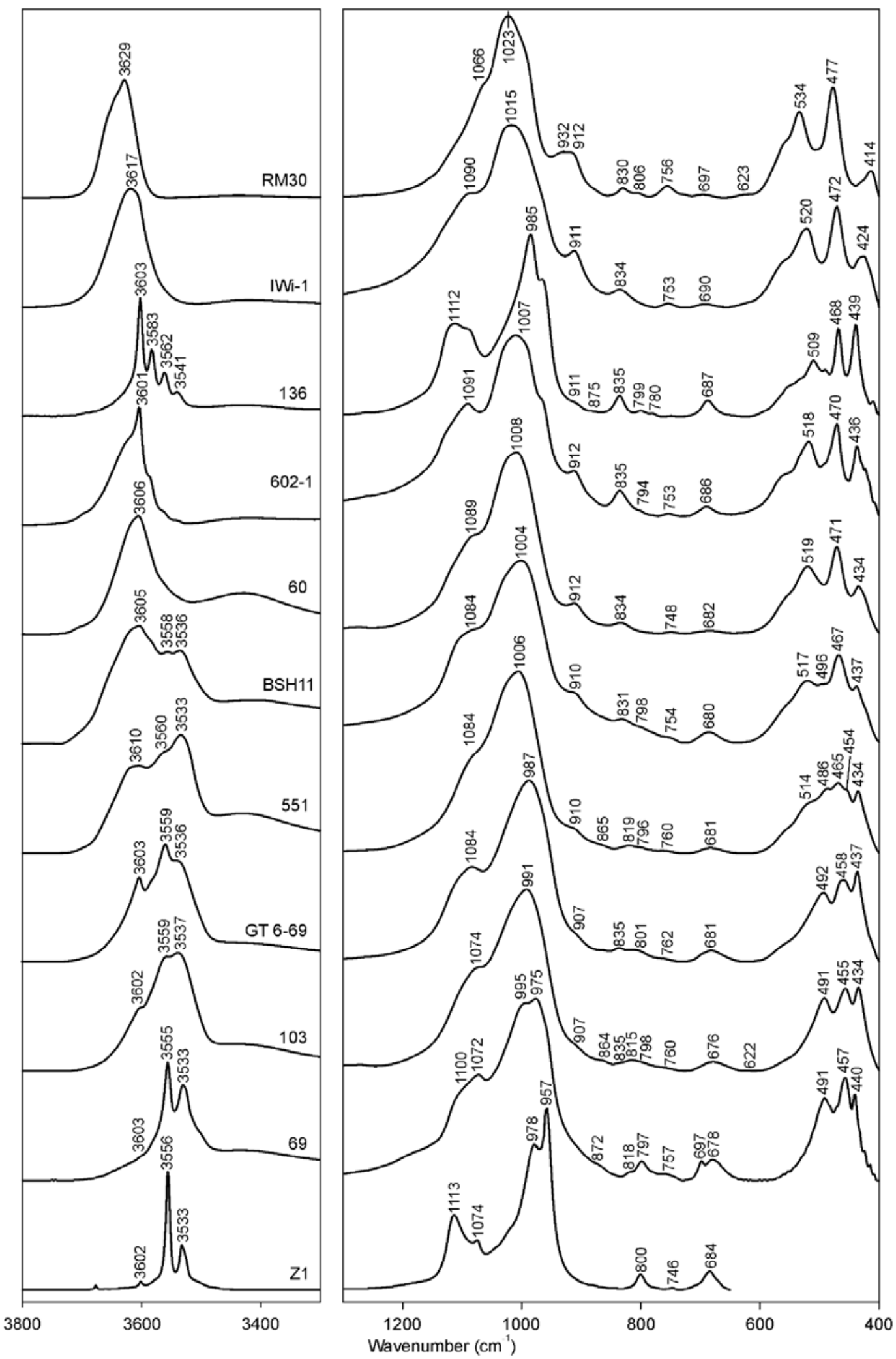

Figure 1. Selected FTIR spectra of K-dioctahedral $1 M$ micas: RM30-( $\mathrm{Mg}, \mathrm{Fe})$-poor illite; Iwi-1Mg-rich illite; 136-aliminoceladonite; 602-1—aluminoceladonite; 60-Mg-rich, Fe-bearing illite; BSH11-Fe-illite; 551-Al-glauconite; GT6-69 and 103-glauconites; 69-celadonite; Z1—celadonite. 


\subsection{Si-O Bending Vibration Modes}

Three sharp bands in the region of $600-400 \mathrm{~cm}^{-1}$ are typical for all dioctahedral micas and are conventionally assigned to the $\mathrm{Si}-\mathrm{O}\left(\delta_{1}\right), \mathrm{Si}-\mathrm{O}-\mathrm{Si}\left(\delta_{2}\right)$ and $\mathrm{Si}-\mathrm{O}-\mathrm{M}\left(\delta_{3}\right)$ bending vibrations, where $\delta_{1}$ and $\delta_{3}$ are the lower- and the higher-wavenumber bands, respectively, and $\mathrm{M}=$ octahedral $\mathrm{Al}$ or $\mathrm{Fe}$ cation $[19,26]$. According to [12], the Si-O bending vibrations are strongly coupled with the vibrations of the octahedral cations and with translator vibrations of hydroxyl groups.

In Fe-poor K-dioctahedral $1 M$ micas (the illite-aluminoceladonite series), strong correlations are observed between the spectroscopic characteristics of the $\mathrm{Si}-\mathrm{O}$ bending region and both tetrahedral and octahedral cation composition. With increasing $\mathrm{Si}$ and $\mathrm{Mg}$ contents from $(\mathrm{Mg}$, $\mathrm{Fe}$ )-poor illite to aluminoceladonite through $\mathrm{Mg}$-rich illite, the two "outer" bands in the $\mathrm{Si}-\mathrm{O}$ bending vibrations triplet $\left(\delta_{1}\right.$ and $\left.\delta_{3}\right)$ move toward the "middle" one, so that $\delta_{1}$ and $\delta_{3}$ are shifted from 414 to $439 \mathrm{~cm}^{-1}$ and from 535 to $509 \mathrm{~cm}^{-1}$, respectively; the wavenumber of the "middle" $\mathrm{Si}-\mathrm{O}-\mathrm{Si}$ bending vibration, $\delta_{2}$, decreases slightly from 477 to $468 \mathrm{~cm}^{-1}$ (Figure 1; Table 3). These regularities are similar to those reported by [14] for the transition from synthetic muscovite to synthetic aluminoceladonite, although in the $\mathrm{Si}-\mathrm{O}$ bending region, Velde [14] only discussed the shifts $\delta_{3}$ to lower wavenumbers.

Beran et al. [65] assigned the band at $437 \mathrm{~cm}^{-1}$ in silicate structures to $\mathrm{Mg}-\mathrm{O}$ stretch $+\mathrm{O}-\mathrm{Si}-\mathrm{O}$ bend . The shift of the $\mathrm{Si}-\mathrm{O}$ bending mode $\delta_{1}$ to greater wavenumbers in the series illite-aluminoceladonite may be therefore associated with the growing influence of the $\mathrm{Mg}-\mathrm{O}$ stretching vibration, taking into account that the relative intensity of $\delta_{1}$ with respect to $\delta_{2}$ increases with increasing Mg contents (Figure 1). The correlations between the position of this band and ${ }^{\mathrm{IV}} \mathrm{Al}$ and $\mathrm{Mg}$ contents are equally strong and described by a quadratic (Figure 2a) and linear (Figure $2 b$ ) regressions, respectively.

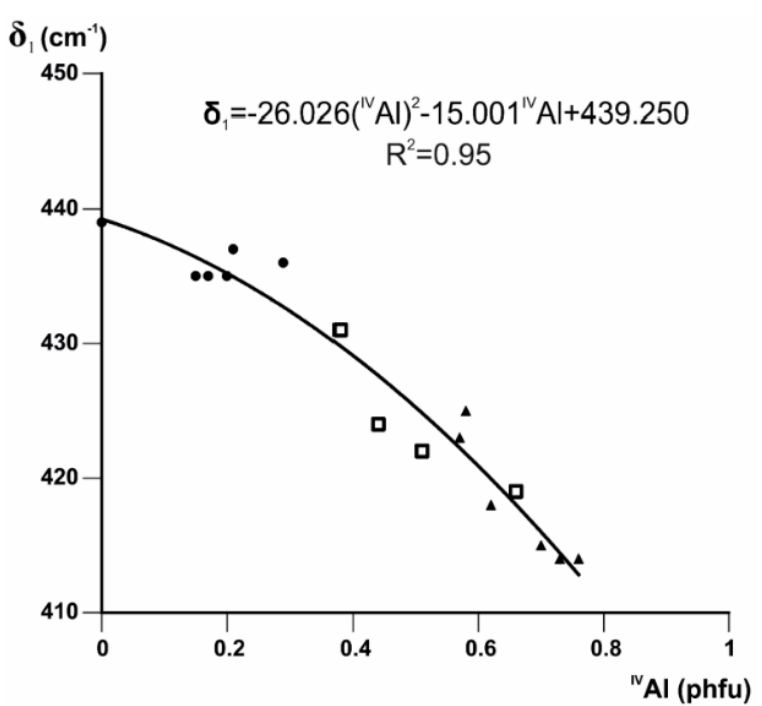

(a)

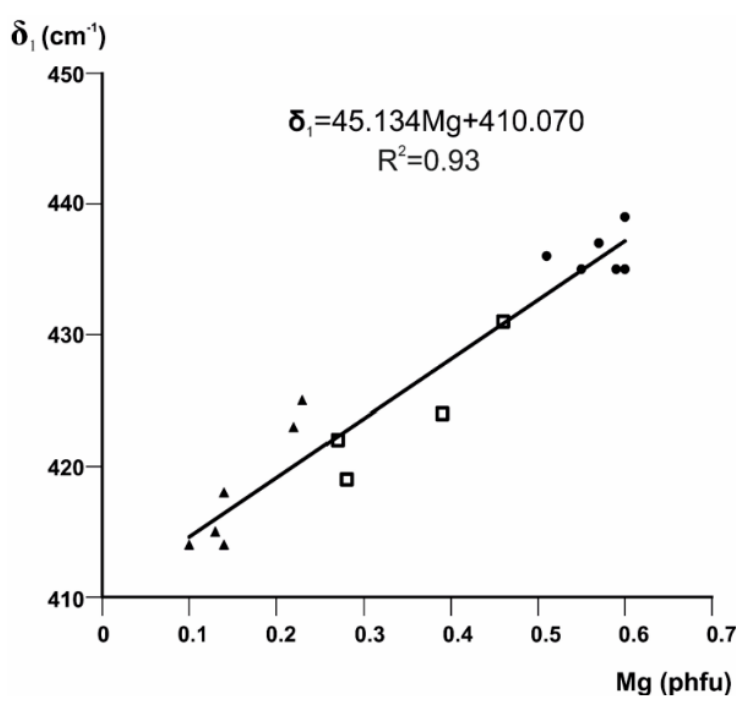

(b)

Figure 2. Band positions $\left(\mathrm{cm}^{-1}\right)$ of $\delta_{1}$ in Fe-poor K-dioctahedral $1 M$ micas plotted vs. (a) ${ }^{\mathrm{IV}} \mathrm{Al}$ and (b) $\mathrm{Mg}$ contents (cations p.h.f.u.). Symbols: triangle $=(\mathrm{Mg}, \mathrm{Fe})$-poor illites, square $=\mathrm{Mg}$-rich illites, circle $=$ aluminoceladonites.

The absorption band $\delta_{2}$ is interpreted as the $\mathrm{Si}-\mathrm{O}-\mathrm{Si}$ bending vibration $[20,22,64]$ coupled with $\mathrm{Al}-\mathrm{O}-\mathrm{Al}$ bend [65]. The decrease in $\delta_{2}$ with decreasing tetrahedral and octahedral $\mathrm{Al}$ and increasing octahedral $\mathrm{Mg}$ contents is described by quadratic regression equations with $\mathrm{R}^{2}=0.77,0.77$ and 0.81 , respectively, with considerable scatter (Figure 3a-c). 

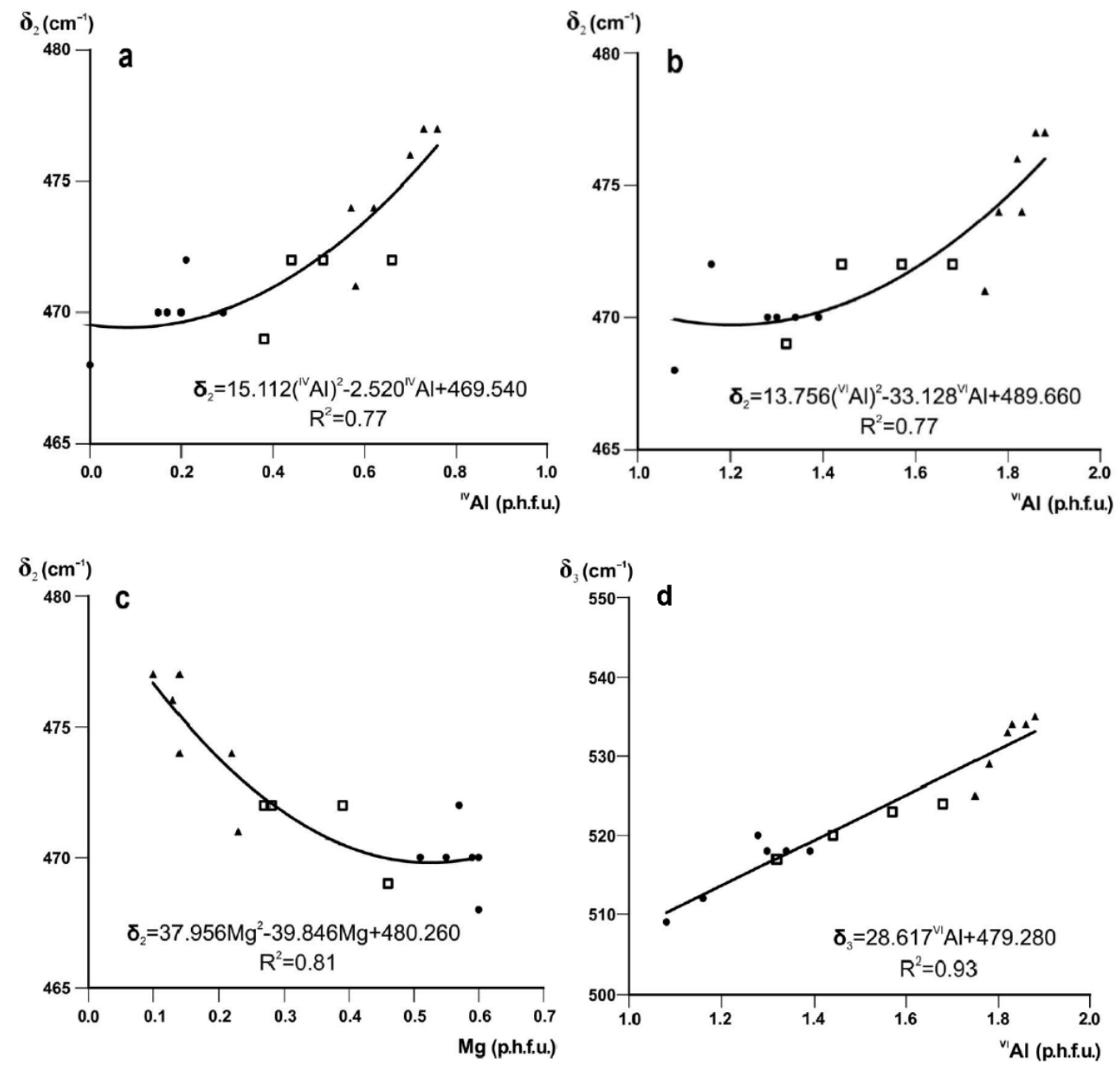

Figure 3. Band positions $\left(\mathrm{cm}^{-1}\right)$ of $\delta_{2}$ and $\delta_{3}$ in Fe-poor K-dioctahedral $1 M$ micas plotted vs. octahedral cation contents: (a) $\delta_{2}$ vs. ${ }^{\mathrm{IV}} \mathrm{Al} ;(\mathbf{b}) \delta_{2}$ vs. ${ }^{\mathrm{VI}} \mathrm{Al}$; (c) $\delta_{2}$ vs. $\mathrm{Mg} ;$ (d) $\delta_{3}$ vs. ${ }^{\mathrm{VI}} \mathrm{Al}$ (cations p.h.f.u.). Symbols as in Figure 2.

The $\delta_{3}$ mode is assigned to $\mathrm{Si}-\mathrm{O}-\mathrm{Al}$ bending vibration (octahedral $\mathrm{Al}$ ) [22]. The shift of $\delta_{3}$ to lower wavenumbers in the transition from muscovite-like illite to phengite-like illite to aluminoceladonite may be associated with the increasing $\mathrm{Si}-\mathrm{O}-\mathrm{Al}$ angle as a result of increasing tetrahedral elongation in combination with increasing octahedral sheet thickness. Experimental structural data show that the tetrahedral elongation angle $\mathrm{O}_{\mathrm{bas}}-\mathrm{T}-\mathrm{O}_{\mathrm{ap}}$ is $\sim 110-111^{\circ}$ in muscovite [66], $112^{\circ}$ in phengite [67] and $\sim 113^{\circ}$ in aluminoceladonite [68], while the octahedral sheet thickness simultaneously increases from $\sim 2.090$ to $2.164 \AA[69,70]$. The increase in the $\mathrm{Si}-\mathrm{O}-\mathrm{Al}$ angle should lower the vibration energy [14], so that the $\delta_{3}$ mode shifts to lower wavenumbers. The position of $\delta_{3}$ in the series illite-aluminoceladonite is strongly correlated with ${ }^{\mathrm{VI}} \mathrm{Al}\left(\mathrm{R}^{2}=0.93\right.$, Figure 3d).

The equations given in Figures 2 and $3 \mathrm{~d}$ can be used to evaluate the amounts of tetrahedral $\mathrm{Al}$, octahedral $\mathrm{Mg}$, and octahedral $\mathrm{Al}$ cation contents with an $e s d$ of $0.06,0.05$, and 0.075 cations p.h.f.u., respectively [7].

A possible explanation for the band shifts in the $\mathrm{Si}-\mathrm{O}$ bending region in the series $(\mathrm{Mg}, \mathrm{Fe})$-poor illite-Mg-rich illite-aluminoceladonite is provided by a comparison of the spectra of samples RM30 and $136\left(\mathrm{Mg}\right.$, Fe-poor illite and aluminoceladonite, respectively) with that of pyrophyllite $\mathrm{Al}_{2} \mathrm{Si}_{4} \mathrm{O}_{10}(\mathrm{OH})_{2}$ (Figure 4) in the region $550-400 \mathrm{~cm}^{-1}$. Owing to the identical tetrahedral cation composition, the spectrum of aluminoceladonite in the region of $\mathrm{Si}-\mathrm{O}$ bending vibrations might be expected to be 
similar to that of pyrophyllite. In reality, however, the band positions in spectra of aluminoceladonite 136 and pyrophyllite differ dramatically: 439 vs. 419,468 vs. 482 and 509 vs. $541 \mathrm{~cm}^{-1}$ (Figure 4). At the same time, the maximum absorption in the pyrophyllite spectrum is observed at positions close to those of the illites of muscovite-like composition having $0.70-0.85{ }^{\mathrm{IV}} \mathrm{Al}$ (e.g., 414,477 and $534 \mathrm{~cm}^{-1}$, sample RM30) (Figure 4). These results may imply that the influence of octahedral cation composition on the band positions in the $\mathrm{Si}-\mathrm{O}$ bending region is stronger than that of the composition of the tetrahedral sheet and the presence or absence of the interlayer cations. In other words, the presence of the interlayer $\mathrm{K}$ and tetrahedral $\mathrm{Al}$ in the muscovite structure (as opposed to pyrophyllite) are mutually compensated, so that the similarity in the octahedral composition becomes a major factor responsible for the similarity of the muscovite and pyrophyllite spectra. In particular, the similar albeit slightly higher $\delta_{3}$ in pyrophyllite as compared to that of muscovite is associated with somewhat smaller tetrahedral elongation angle $\left(109.4^{\circ}\right)$ and octahedral sheet thickness $(2.079 \AA)$ in the pyrophyllite structure, as compared to $110-111^{\circ}$ and $2.090-2.095 \AA$, respectively, in muscovite $[69,70]$ leading to an even smaller $\mathrm{Si}-\mathrm{O}-\mathrm{Al}$ angle.

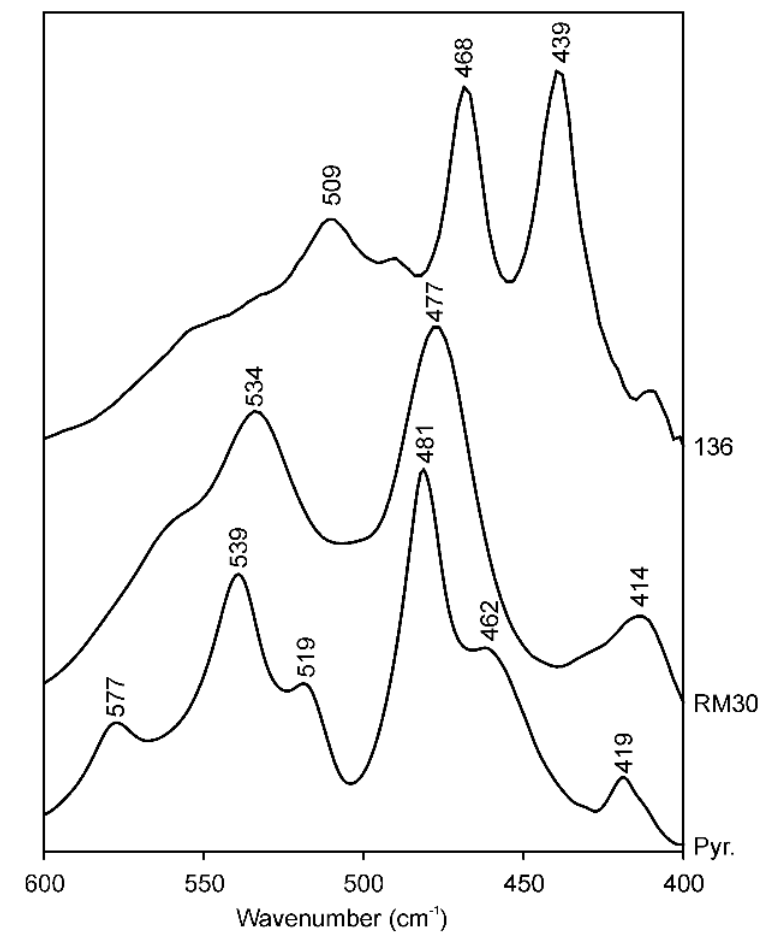

Figure 4. FTIR spectra of (a) aluminoceladonite 136, (b) illite RM30 and (c) pyrophyllite (North Carolina) in the Si-O bending region $\left(600-400 \mathrm{~cm}^{-1}\right)$.

In the $\mathrm{Si}-\mathrm{O}$ bending region of Fe-bearing, $\mathrm{K}$-dioctahedral micas, the positions of the lower wavenumber band, $\delta_{1}$, varies within a narrow range $\left(440-434 \mathrm{~cm}^{-1}\right)$ for all the samples with a very loose trend to decreasing with increasing Fe contents. The position of the $\delta_{2}$ band, which corresponds to the $\mathrm{Si}-\mathrm{O}-\mathrm{Si}$ bending vibration, tends to decrease with decreasing $\mathrm{Al}$ and increasing Fe cation contents from $\sim 470 \mathrm{~cm}^{-1}$ in illites and Fe-illites to $453-463 \mathrm{~cm}^{-1}$ in glauconites and celadonites. Simultaneously, the $\delta_{3}$ band shifts from $514-526 \mathrm{~cm}^{-1}$ corresponding to the $\mathrm{Si}-\mathrm{O}-\mathrm{Al}$ vibration, to $483-499 \mathrm{~cm}^{-1}$ ( $\mathrm{Si}-\mathrm{O}-\mathrm{Fe}$ ) (Table 3). The shift of the $\delta_{3}$ mode to lower wavenumbers with increasing Fe for Al substitution may be associated with an increase in the $\mathrm{Si}-\mathrm{O}-{ }^{\mathrm{VI}} \mathrm{M}$ angle due to an increase in the octahedral sheet thickness, which, in turn, reduces the vibration energy [14]. Another reason is that an increase in the total mass of cations in the vibrating system for cations of the same valence ( $\mathrm{Si}-\mathrm{O}-\mathrm{Al}$ vs. $\mathrm{Si}-\mathrm{O}-\mathrm{Fe}^{3+}$ ) decreases the wavenumber [18]. 
The samples in the Fe-bearing mica series therefore fall into two distinct groups: for $K_{A l} \geq 0.6$, $\delta_{2}$ is at $469 \pm 2 \mathrm{~cm}^{-1}$ and $\delta_{3}$ is at $520 \pm 6 \mathrm{~cm}^{-1}$; for $K_{A l}<0.5, \delta_{2}$ is at $458 \pm 5 \mathrm{~cm}^{-1}$ and $\delta_{3}$ is at 491 $\pm 8 \mathrm{~cm}^{-1}$ (Figure 5a,b). Samples of highly heterogeneous cation composition, such as Fe-illites and Al-glauconites, display, in addition, vibration modes typical for $\delta_{2}$ and $\delta_{3}$ of glauconites and celadonites, either as distinct maxima of minor intensity or as shoulders. Specifically, in samples 551 and 555A $\left(K_{A l} \sim 0.5\right)$, the $\mathrm{Si}-\mathrm{O}$ bending region contains, in addition to the $\delta_{1}$ mode, two well-resolved bands at $465-469 \mathrm{~cm}^{-1}$ and $454-455 \mathrm{~cm}^{-1}$ and shoulders at $514-518 \mathrm{~cm}^{-1}$ and $486 \mathrm{~cm}^{-1}$ (Table 3 , Figure 1 (sample 551), Figure 5). Similarly, the glauconite sample 402/1 $\left(K_{A l}=0.40\right)$, in addition to $\delta_{2}$ at $453 \mathrm{~cm}^{-1}$, shows a second $\mathrm{Si}-\mathrm{O}-\mathrm{Si}$ bending band at $467 \mathrm{~cm}^{-1}$ (Table 3 ). These peculiarities reflect the phase microheterogeneity, which was revealed by XRD powder diffraction for samples 551 and 402/1 [9] and is likely to be present in sample 555A, as its cation composition is very close to that of sample 551. On the whole, the plots of $\delta_{2}$ and $\delta_{3}$ vs. $\mathrm{Fe}_{\text {total }}=\mathrm{Fe}^{2+}+\mathrm{Fe}^{3+}$ (Figure 5) show a wider scatter of points than similar dependencies of bending and stretching $\mathrm{Si}-\mathrm{O}$ vibration band positions on cation composition in Fe-poor dioctahedral micas $1 M$. This may be associated with a much higher degree of crystal-chemical heterogeneity of Fe-bearing varieties and especially glauconites and Al-glauconites [9].

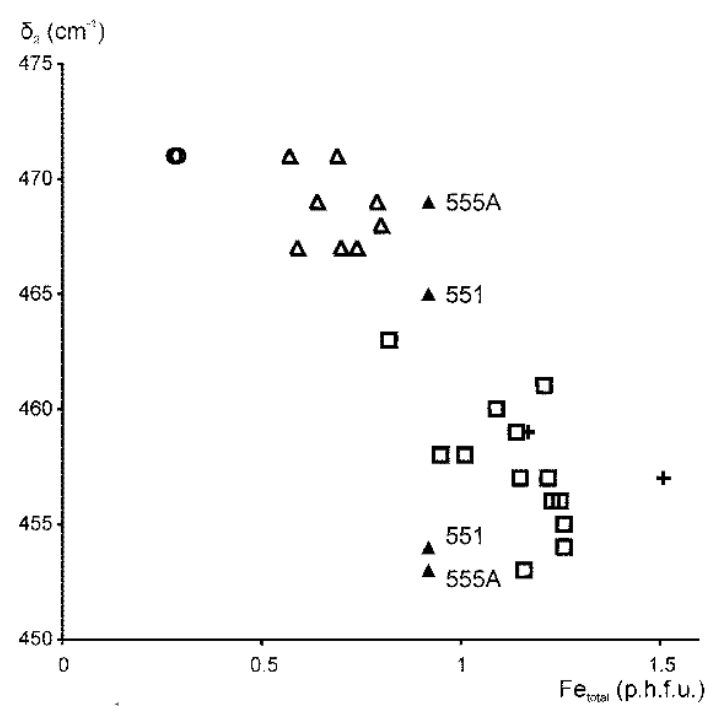

(a)

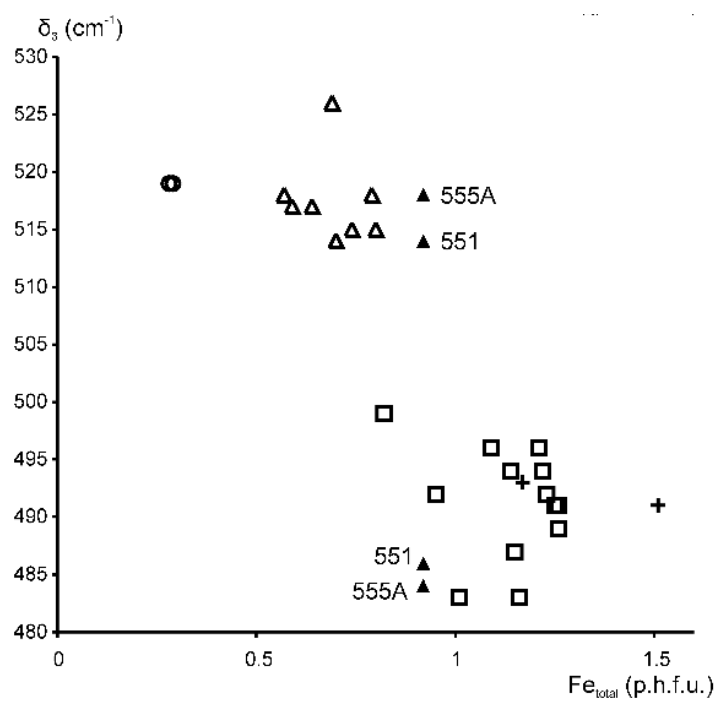

(b)

Figure 5. Band positions $\left(\mathrm{cm}^{-1}\right)$ of $(\mathbf{a}) \delta_{2}$ and (b) $\delta_{3}$ in Fe-bearing K-dioctahedral $1 M$ micas plotted vs. $\mathrm{Fe}_{\text {total }}$ contents (cations p.h.f.u.). Symbols: open circles-Fe-bearing Mg-rich illites $\left(K_{A l}=0.9\right)$, open triangles-Fe-illites and Al-glauconites $\left(K_{A l}=0.6-0.75\right)$, black triangles-Al-glauconites $\left(K_{A l}=0.5\right)$, open squares-glauconites $\left(K_{A l}<0.5\right)$, crosses—celadonites $\left(K_{A l}<0.15\right)$.

\subsection{Si-O Stretching Vibration Modes}

In Fe-poor K-dioctahedral $1 M$ micas, the profiles and positions of the bands in this region are correlated with both tetrahedral and octahedral cation composition. With decreasing $\mathrm{Al}$ for $\mathrm{Si}$ substitution in the series (Mg, Fe)-poor illite-Mg-rich illite-aluminoceladonite, the Si-O stretching band, $v(\mathrm{SiO})$ shifts from $1024 \mathrm{~cm}^{-1}\left({ }^{\mathrm{IV}} \mathrm{Al}=0.76\right.$, sample $\left.\mathrm{SG}-4\right)$ to $985 \mathrm{~cm}^{-1}$ ( ${ }^{\mathrm{IV}} \mathrm{Al}=0$, sample 136), and the $\mathrm{Si}-\mathrm{O}$ apical stretching mode, $v\left(\mathrm{SiO}_{\text {apical }}\right)$, transforms from a shoulder at $1067 \mathrm{~cm}^{-1}$ into a well-resolved band at $1112 \mathrm{~cm}^{-1}$ (Table 3, Figure 1). With increasing Si and decreasing octahedral Al contents, the non-bridging tetrahedral cation-anion $\left(\mathrm{T}-\mathrm{O}_{\text {apical }}\right)$ distance is significantly shortened and strengthened with respect to the mean bridging ( $\left.\mathrm{T}-\mathrm{O}_{\text {basal }}\right)$ distance due to increasing under-saturation of the apical oxygen anion with respect to negative charge. This effect is confirmed by numerous structure refinements of dioctahedral micas-2 $M_{1}$ [66-68] and can be described quantitatively in terms of the bond strength sum variation [70]. Accordingly, the two Si-O stretching modes become resolved, as $v(\mathrm{SiO})$ shifts to lower and $v\left(\mathrm{SiO}_{\text {apical }}\right)$ shifts to greater wavenumbers. Both trends can be described 
by quadratic regressions relating $v(\mathrm{SiO})$ and $v\left(\mathrm{SiO}_{\text {apical }}\right)$ to ${ }^{\mathrm{IV}} \mathrm{Al}$ (Figure 6a,b), with the correlation coefficients $\mathrm{R}^{2}=0.76$ and 0.77 , respectively. A much stronger correlation is observed between $v(\mathrm{SiO})$ and octahedral Al contents, ${ }^{\mathrm{VI}} \mathrm{Al}\left(\mathrm{R}^{2}=0.94\right.$, Figure $\left.6 \mathrm{c}\right)$.

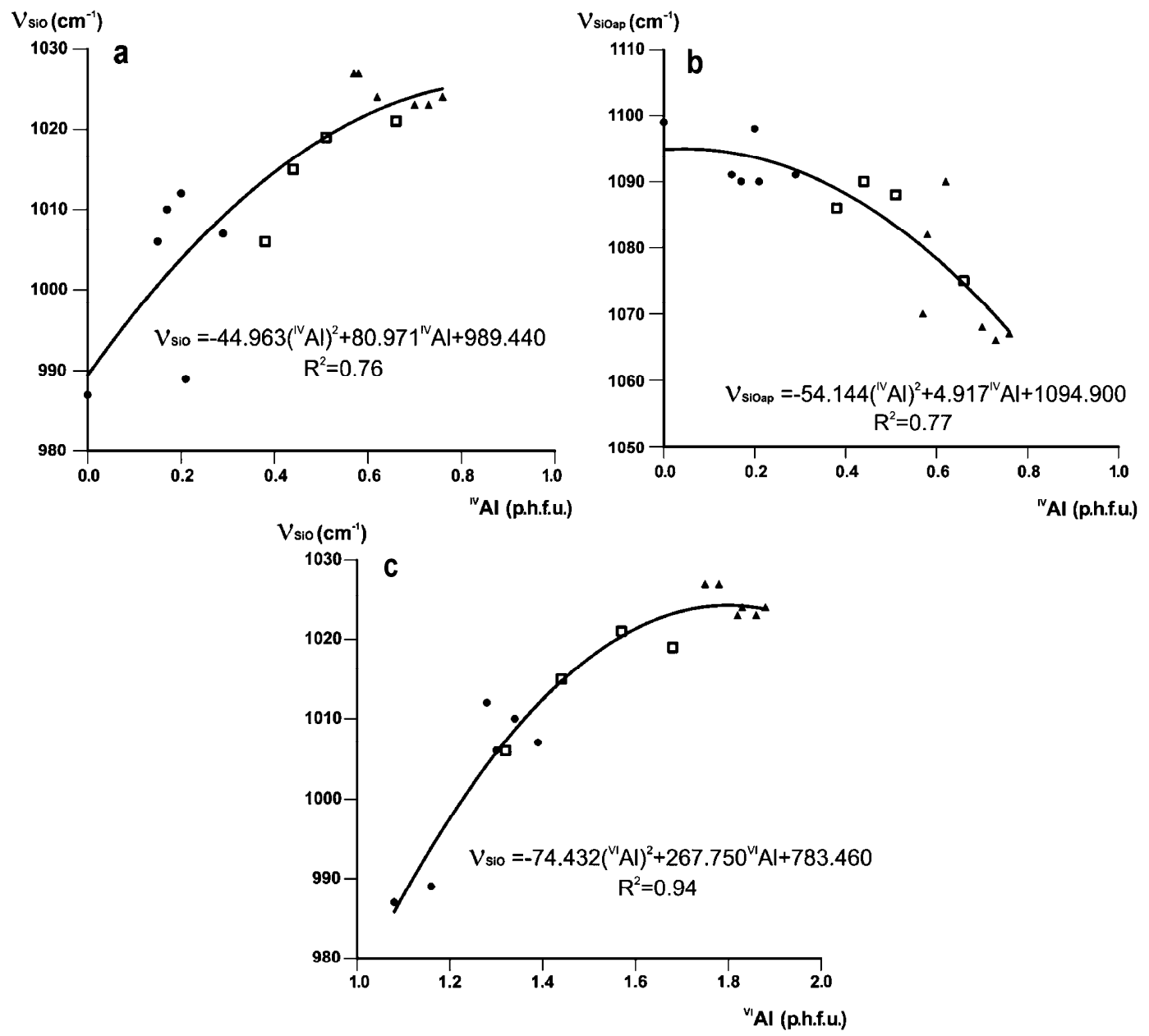

Figure 6. Band positions $\left(\mathrm{cm}^{-1}\right)$ of $(\mathbf{a}) \vee(\mathrm{SiO})$ and $(\mathbf{b}) \vee\left(\mathrm{SiO}_{\text {apical }}\right)$ plotted against ${ }^{\mathrm{IV}} \mathrm{Al}$ contents (cations p.h.f.u.), and (c) $v(\mathrm{SiO})$ plotted vs. ${ }^{\mathrm{IV}} \mathrm{Al}$ contents for Fe-poor K-dioctahedral $1 M$ micas (cations p.h.f.u.). Symbols as in Figure 2.

In Fe-bearing $\mathrm{K}$-dioctahedral micas $1 M$, the $\mathrm{Si}-\mathrm{O}$ stretching region is the least informative as to the distinguishing features [8], as the $v(\mathrm{SiO})$ band is at $987-1017 \mathrm{~cm}^{-1}$ in Mg-rich, Fe-bearing illites, Fe-illites, Al-glauconites and glauconites show little or no correlation with either tetrahedral or octahedral cation composition. The $v\left(\mathrm{SiO}_{\text {apical }}\right)$ mode appears either as a distinct band or a shoulder within the 1070-1100 $\mathrm{cm}^{-1}$ range (Table 3). Celadonite is an exception showing either two sharp, well-resolved bands (978 and $1090 \mathrm{~cm}^{-1}$, sample TAIH) or two sharp bands (975 and $1082 \mathrm{~cm}^{-1}$ ) with shoulders at 995 and $1100 \mathrm{~cm}^{-1}$ (sample 69), or four sharp bands $\left(957,978,1074\right.$ and $1113 \mathrm{~cm}^{-1}$, sample Z1) (Table 3, Figure 1).

\subsection{The $950-600 \mathrm{~cm}^{-1}$ Region}

The region 950-600 $\mathrm{cm}^{-1}$ contains, along with the $\mathrm{OH}$ bending bands, which are located on the low-wavenumber side of the $\mathrm{Si}-\mathrm{O}$ stretch, a number of absorption bands corresponding to other types of vibrations ( $\mathrm{Al}-\mathrm{O}$ and $\mathrm{Fe}-\mathrm{O}$ out-of-plane, $\mathrm{Al}-\mathrm{O}-\mathrm{Si}$ in-plane modes, etc.), which is a series hindrance to unambiguous interpretation of this spectral region. 
In most cases, the micas in the illite-aluminoceladonite series display the $\delta(\mathrm{AlOHAl})$ vibration mode as a distinct band at $909-918 \mathrm{~cm}^{-1}$. Some muscovite-like illites (samples \#1-4, Table 4; sample RM30, Figure 7) show a plateau resulting from a superposition of two bands at 912-918 and $932-934 \mathrm{~cm}^{-1}$. Aluminoceladonites 136 and $\mathrm{Z} 2$ show the $\delta(\mathrm{AlOHAl})$ mode as an inflection at $910-912 \mathrm{~cm}^{-1}$ on the low-wavenumber side of the $v(\mathrm{SiO})$ band (Figure 7 , Table 4$)$. Depending on the octahedral $\mathrm{Al}$ cation content, the $\delta(\mathrm{AlOHAl})$ band appears in the spectra of Fe-illites, Al-glauconites and glauconites, either as a distinct maximum (sample 560/3) or a shoulder, at $907-915 \mathrm{~cm}^{-1}$; in some glauconites, it can only be identified in the second derivative (Table 4). Celadonite $\mathrm{TAIH}$ with ${ }^{\mathrm{VI}} \mathrm{Al}=0.16$ a.p.h.f.u. shows a week shoulder at $908 \mathrm{~cm}^{-1}$, whereas in the other celadonite spectra, this band is absent.

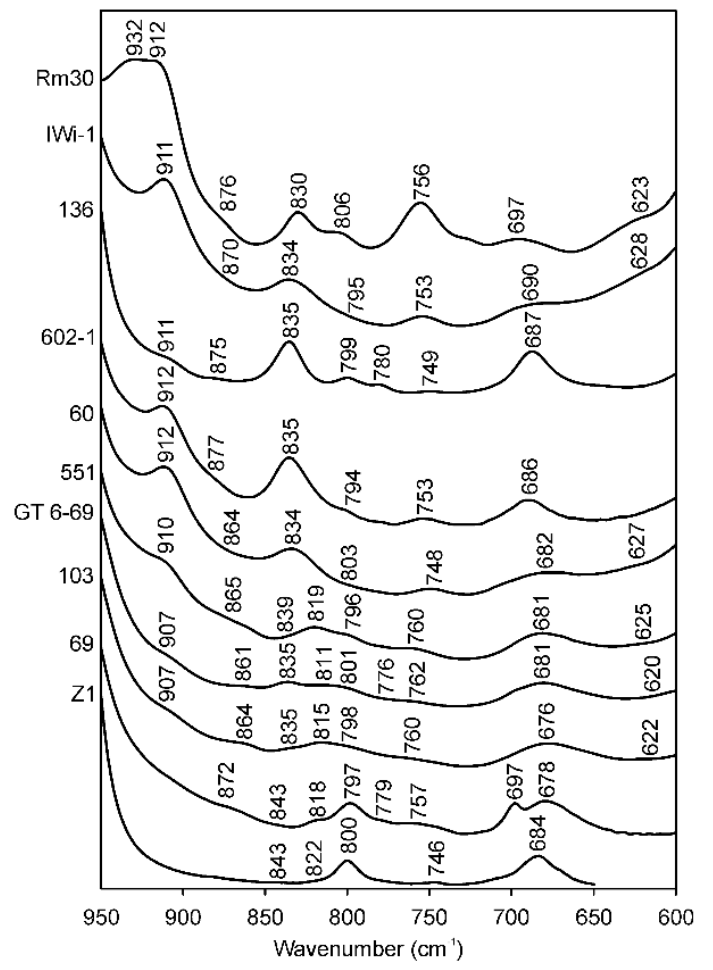

Figure 7. FTIR spectra of selected samples in the region of $950-600 \mathrm{~cm}^{-1}$. RM30- $(\mathrm{Mg}$, Fe)-poor illite; Iwi-1-Mg-rich illite; 136-aliminoceladonite; 602-1-aluminoceladonite; 60-Mg-rich, Fe-bearing illite; BSH11-Fe-illite; 551-Al-glauconite; GT6-69 and 103-glauconites; 69-celadonite; Z1—celadonite.

The band at $\sim 875-880 \mathrm{~cm}^{-1}$, which either appears as a shoulder or can be identified in the second derivative in the spectra of illites and aluminoceladonites, is attributed to the $\mathrm{Al}-\mathrm{O}-\mathrm{Al}$ vibration [20]. Most of the Fe-bearing mica varieties show a shoulder at $\sim 860-865$ or $\sim 870-880 \mathrm{~cm}^{-1}$ (Table 4 ), which, in most cases, is displayed as two components, $860-869$ and $873-888 \mathrm{~cm}^{-1}$ in the second derivative. These bands should refer to $\delta\left(\mathrm{AlOHFe}^{3+}\right)$, which Farmer [12] identified at $890 \mathrm{~cm}^{-1}$, and Madejová et al. [26] at $865 \mathrm{~cm}^{-1}$.

Independent of $\mathrm{Mg}$ content, all illites, Fe-illites, and aluminoceladonites show distinct bands at $824-838 \mathrm{~cm}^{-1}$, the $\delta(\mathrm{AlOHMg})$ band coupled with the Al-O out-of-plane vibration [12,20] (Table 4). This band, therefore, cannot be considered as unambiguously indicative of $\mathrm{Mg}$-rich illite or aluminoceladonite; and in Fe-illites, it may include a contribution from $\delta\left(\mathrm{Fe}^{3+} \mathrm{OH} \mathrm{Fe}^{3+}\right)$ at $\sim 820 \mathrm{~cm}^{-1}$. Al-glauconites, glauconites, and celadonites show a distinct band at $811-823 \mathrm{~cm}^{-1}$, $\delta\left(\mathrm{Fe}^{3+} \mathrm{OH} \mathrm{Fe}{ }^{3+}\right)$ and a weak band, shoulder or second-derivative minimum at $835-843 \mathrm{~cm}^{-1}$, which may correspond, depending on the cation composition, to $\delta(\mathrm{AlOHMg})$ and/or to a second $\delta\left(\mathrm{Fe}^{3+} \mathrm{OHFe}^{3+}\right)$ mode [71-73] (Al-glauconite KUL2 is an exception, showing a broad band at $824 \mathrm{~cm}^{-1}$ poorly resolved from a band at $801 \mathrm{~cm}^{-1}$ ). Gates [73] suggested that in natural nontronites, the band at $839-846 \mathrm{~cm}^{-1}$ is 
related to tetrahedral $\mathrm{Fe}^{3+}$. This might be true for celadonite $\mathrm{TAIH}$, which may contain $\sim 0.2$ tetrahedral $\mathrm{Fe}^{3+}$ cations p.h.f.u., but not for samples 69 and Z1, which have no tetrahedral $\mathrm{Fe}^{3+}$ [18].

Depending on the cation composition, the distinct band or shoulder or a minimum in the second derivative at $\sim 795-805 \mathrm{~cm}^{-1}$ present in all the spectra (Table 4) may refer to either the Al-O-Al vibration [20], to $\delta\left(\mathrm{Fe}^{3+} \mathrm{OHMg}\right)$ and/or $\delta\left(\mathrm{Fe}^{2+} \mathrm{OH} \mathrm{Fe}{ }^{3+}\right)[12,26]$, or to silica or quartz admixtures [26,74]. The conventional assignment of the band at $\sim 800 \mathrm{~cm}^{-1}$ to $\delta\left(\mathrm{Fe}^{2+} \mathrm{OH} \mathrm{Fe}{ }^{3+}\right)$ is in fair agreement with ab initio calculations $\left(808 \mathrm{~cm}^{-1},[75]\right)$ but disagrees with the prediction of cation mass-valence sum (CM-VS) approach $\left(766 \mathrm{~cm}^{-1},[72,73]\right)$, making the interpretation still more complicated. Other types of $\mathrm{OH}$-linked cation pairs, such as $\mathrm{Fe}^{2+} \mathrm{OHFe}^{2+}, \mathrm{AlOHFe}^{2+}$ and $\mathrm{MgOHMg}$, which are revealed in the $\mathrm{OH}$-stretching region (see below), are difficult to identify in the $\mathrm{OH}$-bending region. The corresponding bending bands are predicted at 714, 810 and $776 \mathrm{~cm}^{-1}$, respectively, by the CM-VS approach [72,73] and at 691, 820 and $765 \mathrm{~cm}^{-1}$, respectively, by ab initio calculations [75] and would therefore overlap with other types of absorption bands.

Attempts have been made to decompose and curve-fit the $\mathrm{OH}$-bending region, though not for micas but for smectites and mixed-layer illite-smectites $[60,62,73]$. The interpretation of the OH-bending vibrations, however, is complicated not only by bands overlapping but also by the ambiguity in band attributions $[72,73,75]$, as well as by the uncertainty in the baseline correction in the $\mathrm{OH}$-bending region.

The band at $750 \mathrm{~cm}^{-1}$ is conventionally attributed to the Al-O-Si in-plane vibration $[12,16,26]$, although Beran [20] assigns it to the Al-O-Al in-plane vibration. In any event, the presence of this band indicates Al-for-Si substitution in the tetrahedral sheet. A well-defined band at $753 \pm 3 \mathrm{~cm}^{-1}$ is observed in the spectra of all illites irrespective of the amount of tetrahedral $\mathrm{Al}$ cations, whereas Fe-illites, Al-glauconites and glauconites display a band or shoulder at 753-763 $\mathrm{cm}^{-1}$ (Table 4). Despite the very low or zero tetrahedral Al contents, all aluminoceladonites and celadonites show a weak but distinct absorption band at 746-760 $\mathrm{cm}^{-1}$ (except for celadonite 69 , which nevertheless shows a shoulder at $757 \mathrm{~cm}^{-1}$ ). Further investigation is therefore needed to explain the presence of this band in celadonite and aluminoceladonite spectra.

The band at $686-699 \mathrm{~cm}^{-1}$ in the spectra of Fe-poor mica varieties (Table 4) is assigned to Si-O [64] or $\mathrm{Si}-\mathrm{O}-\mathrm{Al}{ }^{\mathrm{VI}}$ [20] vibrations; the band at $\sim 680-685 \mathrm{~cm}^{-1}$ in Fe-bearing micas is attributed to the $\mathrm{Fe}-\mathrm{O}$ out-of-plane vibration [26]. In varieties of mixed cation composition, such as Fe-illites and Al-glauconites the band at $680-691 \mathrm{~cm}^{-1}$ may result from superposition of the above absorption bands. In celadonites, however, Weiszburg et al. [23] assigned this band to the second libration of $\mathrm{Fe}^{3+}-\mathrm{OH}-\mathrm{Mg}$ and $\mathrm{Fe}^{3+}-\mathrm{OH}-\mathrm{Fe}^{3+}$.

The band at $618-628 \mathrm{~cm}^{-1}$ in some of the illites and aluminoceladonites spectra (or spectra second derivatives) is most probably due to the presence of smectite interlayers $(5 \%-16 \%$, [7]) and corresponds to coupled Al-O and Si-O out-of-plane vibrations characteristic of Al-rich dioctahedral smectites [26]. The band at $620-625 \mathrm{~cm}^{-1}$ can be identified in the second derivatives of the spectra of several Fe-illites, Al-glauconites and glauconites, which contain 5\%-10\% of expandable layers.

The $\mathrm{OH}$-bending bands may overlap not only with other types of vibrations of the mica structure but also with those of various common admixtures, such as quartz with characteristic absorption bands at $693-694 \mathrm{~cm}^{-1}, 777-780 \mathrm{~cm}^{-1}$ and $797-801 \mathrm{~cm}^{-1}$, as well as amorphous silica $\left(\sim 800 \mathrm{~cm}^{-1}\right)$ or cristobalite $\left(792-796 \mathrm{~cm}^{-1}\right)[74,76]$. The various carbonate minerals display absorption bands at 1420-1480 $\mathrm{cm}^{-1}, 860-890 \mathrm{~cm}^{-1}$ and 700-740 $\mathrm{cm}^{-1}$ [77]; goethite, a common admixture in Fe-rich micas, shows absorption at 890 and $797 \mathrm{~cm}^{-1}$ [78]. The presence of these admixtures may complicate the interpretation of the spectra. For example, in glauconites 79/73 and 372/70 and celadonites TAIH and 69 , sharp absorption bands at 695-699 $\mathrm{cm}^{-1}$ in combination with bands at $1440-1450 \mathrm{~cm}^{-1}$ may indicate the presence of carbonate admixtures. At the same time, a weak shoulder at $779 \mathrm{~cm}^{-1}$ in combination with a band at 797 in sample 69 suggests that the sharp band at 698 may refer to quartz. In such cases the correct attribution of the absorption bands in the region of interest requires application of other methods, e.g., X-ray diffraction. 
Partial overlap and coupling of the various bands, as well as the existing ambiguities in band assignments, complicate the interpretation of the $950-600 \mathrm{~cm}^{-1}$ region and make it less informative from the point of view of identification. On the other hand, in combination with the data on the Si-O bending and stretching modes, as well as the $\mathrm{OH}$-stretching vibrations, the band positions in this region may provide helpful additional information.

\subsection{The OH Stretching Vibration Modes}

\subsubsection{Methodology}

The FTIR spectrum of a dioctahedral mica in the $\mathrm{OH}$-stretching region results from a superposition of $\mathrm{OH}$ bands corresponding to specific types of $\mathrm{OH}$-linked cation pairs. The relative integrated intensities of individual bands are proportional to the contents of the corresponding types of cations in the $\mathrm{OH}$-sharing cis-octahedral sites with the absorption coefficients being the same for all cation-pair types $[13,17,18]$.

The positions of the specific cation-OH-cation bands (Table 5), which were identified from spectra decomposition and curve-fitting of IR spectra of dioctahedral mica samples of diverse cation compositions $[17,18]$, depend on the nature of cations in the two OH-sharing cis-octahedral sites and are determined by several competing factors. On the one hand, an increase in the total mass of cations bound to an $\mathrm{OH}$ group decreases the wavenumber. On the other hand, for cations having the same mass but different valences, two opposite trends interact. An increase in the total cation valence decreases the interaction within the $\mathrm{OH}$ group, but simultaneously increases the repulsion between the cations and the hydroxyl proton, thus weakening hydrogen bonds between $\mathrm{OH}$ and two apical oxygen anions in the octahedral sheet and strengthening the bond within the OH group. The latter effect dominates, and therefore an increase in the total cation valence increases the wavenumber. For the $\mathrm{AlOHAl}, \mathrm{AlOHMg}$ and $\mathrm{MgOHMg}$ stretching vibrations, the valence effect prevails over the mass effect, and therefore $v(\mathrm{AlOHAl})>v(\mathrm{AlOHMg})>v(\mathrm{MgOHMg})$. In addition to the $\mathrm{OH}$-stretching vibrations of the mica structure proper, Besson and Drits $[17,18]$ identified the $\mathrm{AlOHAl}, \mathrm{AlOHFe}^{3+}$ and $\mathrm{Fe}^{3+} \mathrm{OHFe}^{3+}$ bands of pyrophyllite- and ferripyrophyllite-like structural fragments present in interlayer-deficient micas at positions close to those observed in pyrophyllite and ferripyrophyllite spectra $[12,79,80]$ (Table 5).

The assumption of the absorption coefficients being the same for all individual OH-stretching bands $[13,18]$ allows the evaluation of the octahedral cation contents from FTIR data and therefore provides a criterion for the validity of the interpretation of the spectrum. The content of a cation $R_{i}$ p.h.f.u. is given by $\mathrm{R}_{\mathrm{i}}=2 \mathrm{~A}_{\mathrm{ii}}+\Sigma_{\mathrm{j}} \mathrm{A}_{\mathrm{ijj}}$ [18], so that, e.g.,

$$
\mathrm{Al}=2 \mathrm{~A}_{\mathrm{AlAl}}+\mathrm{A}_{\mathrm{AlMg}}+\mathrm{A}_{\mathrm{AlFe} 3+}+\mathrm{A}_{\mathrm{AlFe} 2+},
$$

where $\mathrm{Al}$ is the amount of $\mathrm{Al}$ cations p.h.f.u., and $\mathrm{A}_{\mathrm{AlAl}}, \mathrm{A}_{\mathrm{AlMg}}, \mathrm{A}_{\mathrm{AlFe}+}$ and $\mathrm{A}_{\mathrm{AlFe} 2+}$ are the relative integrated intensities of the $\mathrm{AlOHAl}, \mathrm{AlOHMg}, \mathrm{AlOHFe}^{3+}$, and $\mathrm{AlOHFe}^{2+}$ bands, respectively. Correct band attributions and spectrum decomposition/curve-fitting should lead to agreement between the cation composition of the sample obtained from FTIR data and that provided by the crystal-chemical formula. 
Table 5. Positions $v(\mathrm{OH}), \mathrm{cm}^{-1}$ and relative integrated intensities I of $\mathrm{OH}$ stretching bands corresponding to specific OH-bonded cation pairs in the FTIR spectra of selected K-dioctahedral $1 M$ micas; $\chi^{2}$ is the minimization function. (Sample numbers as in Tables $1-4$ ).

\begin{tabular}{|c|c|c|c|c|c|c|c|c|c|c|c|c|c|c|c|c|c|c|c|c|c|c|}
\hline \multirow{2}{*}{$\begin{array}{c}\begin{array}{c}\# \\
\text { Sample }\end{array} \\
\text { Band }\end{array}$} & \multicolumn{2}{|c|}{$\begin{array}{c}1 \\
\text { RM30 }\end{array}$} & \multicolumn{2}{|c|}{$\begin{array}{c}9 \\
\text { IWi-1 }\end{array}$} & \multicolumn{2}{|c|}{$\begin{array}{c}12 \\
602-1\end{array}$} & \multicolumn{2}{|c|}{$\begin{array}{c}17 \\
136\end{array}$} & \multicolumn{2}{|c|}{$\begin{array}{c}26 \\
551\end{array}$} & \multicolumn{2}{|c|}{$\begin{array}{c}27 \\
555 \mathrm{~A}\end{array}$} & \multicolumn{2}{|c|}{$\begin{array}{c}29 \\
103\end{array}$} & \multicolumn{2}{|c|}{$\begin{array}{c}31 \\
3771 \mathrm{~A}\end{array}$} & \multicolumn{2}{|c|}{$\begin{array}{c}35 \\
\text { GT6-69 }\end{array}$} & \multicolumn{2}{|c|}{$\begin{array}{l}43 \\
\mathrm{Z} 1\end{array}$} & \multirow{2}{*}{$\begin{array}{l}{[17,18]} \\
v(\mathrm{OH})\end{array}$} & \multirow{2}{*}{$\begin{array}{c}\begin{array}{c}\text { This } \\
\text { work }\end{array} \\
v(\mathrm{OH}) \\
\end{array}$} \\
\hline & $v(\mathrm{OH})$ & A & $v(\mathrm{OH})$ & $\mathbf{A}$ & $v(\mathrm{OH})$ & $\mathbf{A}$ & $v(\mathrm{OH})$ & $\mathbf{A}$ & $v(\mathrm{OH})$ & $\mathbf{A}$ & $v(\mathrm{OH})$ & $\mathbf{A}$ & $v(\mathrm{OH})$ & $\mathbf{A}$ & $v(\mathrm{OH})$ & A & $v(\mathrm{OH})$ & A & $v(\mathrm{OH})$ & $\mathbf{A}$ & & \\
\hline $\mathrm{Fe}^{2+} \mathrm{OHFe}^{2+}$ & - & - & - & - & - & - & 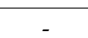 & - & 3500 & 0.062 & 3505 & 0.087 & 3505 & 0.059 & 3505 & 0.051 & 3504 & 0.055 & 3505 & 0.091 & $3505 \pm 2$ & $3503 \pm 3$ \\
\hline $\mathrm{Fe}^{2+} \mathrm{OHFe}^{3+}$ & - & - & - & - & - & - & 3523 & 0.032 & 3517 & 0.107 & 3517 & 0.022 & 3520 & 0.111 & 3516 & 0.048 & 3516 & 0.065 & 3527 & 0.151 & $3521 \pm 3$ & $3521 \pm 6$ \\
\hline $\mathrm{Fe}^{3+} \mathrm{OHFe}^{3+}$ & - & - & - & - & - & - & - & . & 3535 & 0.16 & 3534 & 0.236 & 3533 & 0.138 & 3530 & 0.149 & 3531 & 0.134 & 3533 & 0.119 & $3535 \pm 2$ & $3533 \pm 3$ \\
\hline $\mathrm{Fe}^{3+} \mathrm{OHFe}^{3+}$ & - & - & - & - & - & - & 3541 & 0.076 & - & - & - & - & 3547 & 0.127 & 3544 & 0.104 & 3545 & 0.105 & - & - & - & $3544 \pm 3$ \\
\hline $\mathrm{MgOHFe}^{2+}$ & - & - & - & - & 3542 & 0.020 & - & - & - & - & - & - & - & - & & & - & - & - & - & $3543 \pm 3$ & 3541 \\
\hline $\mathrm{AlOHFe}^{2+}$ & - & - & - & - & 3567 & 0.052 & 3562 & 0.134 & - & - & - & - & - & - & 3560 & 0.071 & & & - & - & $3559 \pm 3$ & $3563 \pm 3$ \\
\hline $\mathrm{MgOHFe}^{3+}$ & - & - & 3566 & 0.072 & - & - & - & - & 3558 & 0.114 & 3559 & 0.118 & 3562 & 0.148 & 3560 & 0.069 & 3560 & 0.154 & 3556 & 0.527 & $3559 \pm 3$ & $3561 \pm 5$ \\
\hline $\mathrm{AlOHFe}^{3+}$ & - & - & - & - & - & - & - & - & 3578 & 0.14 & 3574 & 0.055 & 3575 & 0.095 & 3576 & 0.088 & 3574 & 0.098 & - & - & $3573 \pm 2$ & $3576 \pm 2$ \\
\hline $\mathrm{MgOH}$ & - & - & - & - & 3586 & 0.099 & 3583 & 0.194 & - & - & 3587 & 0.073 & & & 3587 & & 3586 & 0.071 & 3579 & 0.073 & & $3583 \pm 4$ \\
\hline $\mathrm{AlOH}$ & 3610 & 0.166 & 3603 & 0.280 & & & 3603 & & 3602 & & & & & & 3601 & & & & 3602 & 0.029 & & $3605 \pm 5$ \\
\hline AlOHA & 3627 & 0.39 & 3620 & 0.366 & 3619 & 0.2 & 3615 & 0.27 & 3620 & 0.11 & 3623 & 0.1 & 3618 & 0.086 & 3616 & 0.076 & 36 & 0.0 & - & - & & $3621 \pm 6$ \\
\hline $\mathrm{AlOH}$ & & 0.181 & 3640 & 0.109 & 3636 & & 3640 & & & & 3638 & 0.074 & - & - & - & - & 3636 & 0.0 & - & - & & $3641 \pm 5$ \\
\hline AlOHAl & 3659 & 0.181 & - & - & 3661 & 0.042 & 3656 & 0.070 & 3666 & 0.041 & 3663 & 0.033 & 3663 & 0.034 & 3665 & 0.026 & 3656 & 0.026 & - & - & $3658 \pm 3$ & $3661 \pm 5$ \\
\hline $\mathrm{Fe}^{3+} \mathrm{OHFe}^{3+}{ }_{\mathrm{pyr}}$ & - & - & - & - & & - & - & - & - & - & - & & 3638 & 0.049 & 3631 & 0.081 & - & - & - & - & $3631 \pm 3$ & $3634 \pm 4$ \\
\hline $\mathrm{AlOHFe}^{3+}{ }_{\mathrm{pyr}}$ & - & - & 3656 & 0.079 & 3651 & 0.061 & - & - & 3654 & 0.035 & 3652 & 0.041 & - & - & 3649 & 0.05 & - & - & - & - & & $3652 \pm 4$ \\
\hline $\mathrm{AlOHAl}_{\mathrm{pyr}}$ & 3672 & 0.079 & 3672 & 0.094 & 3672 & 0.050 & - & - & 3690 * & 0.020 & 3680 & 0.028 & - & - & 3679 & 0.017 & 3675 & 0.018 & 3677 & 0.009 & $3675 \pm 4$ & $3675 \pm 5$ \\
\hline$x^{2}$ & 1. & & 4. & & 4.2 & & 1.3 & & 6.0 & & 3.7 & & 2.5 & & 5.4 & & 1.2 & & 3. & & & \\
\hline
\end{tabular}

${ }^{*} \mathrm{AlOHAl}_{\mathrm{pyr}}$ of the smectite component (?). 


\subsubsection{Profiles and Positions of $\mathrm{OH}-$ Stretching Bands as a Function of Cation Composition}

K-dioctahedral $1 M$ micas display a variety of band positions and profiles in the $\mathrm{OH}$-stretching region. In most cases (except aluminoceladonites and celadonites), they show a broad band, with or without modulations (Figures 1 and 8), resulting from the superposition of individual cation-OH-cation vibrations. For selected samples, these individual bands were identified from spectrum decomposition and curve-fitting (Table 5, Figure 8). The validity of the spectra interpretation was confirmed by good agreement between cation compositions obtained from FTIR data and those provided by the crystal-chemical formulae (Table 6). The $\chi^{2}$ values varied from 1.13 to 6.04 (Table 5), and the $R^{2}$ values were $\sim 1.00$ for all the decompositions.

Table 6. Octahedral cation compositions of selected samples (cations p.h.f.u.): c.a.-obtained from chemical analysis data; FTIR — calculated from relative integrated intensities of OH-stretching bands.

\begin{tabular}{|c|c|c|c|c|c|c|c|c|c|c|c|c|}
\hline \multirow{2}{*}{ Sample } & \multicolumn{2}{|c|}{ Al } & \multicolumn{2}{|c|}{$\mathrm{Mg}$} & \multicolumn{2}{|c|}{$\mathrm{Fe}^{2+}$} & \multicolumn{2}{|c|}{$\mathrm{Fe}^{3+}$} & \multicolumn{2}{|c|}{$\mathrm{Fe}_{\text {tot }} *$} & \multicolumn{2}{|c|}{$\Sigma_{\text {oct }} * *$} \\
\hline & c.a. & FTIR & c.a. & FTIR & c.a. & FTIR & c.a. & FTIR & c.a. & FTIR & c.a. & FTIR \\
\hline RM30 & 1.86 & 1.83 & 0.14 & 0.17 & - & - & - & - & - & - & 2.00 & 2.00 \\
\hline IWi-1 & 1.44 & 1.50 & 0.39 & 0.35 & - & - & 0.14 & 0.15 & 0.14 & 0.15 & 1.97 & 2.00 \\
\hline $602-1$ & 1.39 & 1.40 & 0.51 & 0.47 & 0.09 & 0.07 & 0.04 & 0.06 & 0.13 & 0.13 & 2.03 & 2.00 \\
\hline 136 & 1.08 & 1.07 & 0.60 & 0.58 & 0.19 & 0.17 & 0.13 & 0.18 & 0.32 & 0.35 & 2.00 & 2.00 \\
\hline 551 & 0.85 & 0.80 & 0.22 & 0.25 & 0.15 & 0.23 & 0.77 & 0.72 & 0.92 & 0.95 & 1.99 & 2.00 \\
\hline $555 \mathrm{~A}$ & 0.76 & 0.70 & 0.34 & 0.39 & 0.16 & 0.20 & 0.76 & 0.72 & 0.92 & 0.92 & 2.03 & 2.00 \\
\hline 103 & 0.37 & 0.42 & 0.40 & 0.37 & 0.11 & 0.23 & 1.15 & 0.98 & 1.26 & 1.21 & 2.03 & 2.00 \\
\hline $3771 \mathrm{~A}$ & 0.64 & 0.56 & 0.28 & 0.29 & 0.19 & 0.22 & 0.96 & 0.92 & 1.15 & 1.14 & 2.07 & 2.00 \\
\hline GT6-69 & 0.57 & 0.62 & 0.47 & 0.41 & n.d. & 0.18 & 0.95 & 0.79 & 0.95 & 0.97 & 1.99 & 2.00 \\
\hline Z1 & 0.05 & 0.05 & 0.73 & 0.70 & 0.26 & 0.33 & 0.96 & 0.92 & 1.22 & 1.25 & 2.00 & 2.00 \\
\hline
\end{tabular}

In both $(\mathrm{Mg}, \mathrm{Fe})$-poor and $\mathrm{Mg}$-rich illites, the $\mathrm{OH}$-stretching region shows a single wide absorption band; the position of maximum absorption depends on the octahedral cation composition. In samples having $0.1-0.27 \mathrm{Mg}$ cations p.h.f.u., the maximum absorption is determined by the AlOHAl vibration at $3627 \pm 3 \mathrm{~cm}^{-1}$ (Table 3). For example, the $\mathrm{OH}$-absorption band in sample RM30 results from the superposition of the AlOHMg band $\left(3610 \mathrm{~cm}^{-1}\right)$, three AlOHAl bands $\left(3627,3645\right.$, and $\left.3659 \mathrm{~cm}^{-1}\right)$ and the AlOHAl band of the pyrophyllite-like component $\left(3672 \mathrm{~cm}^{-1}\right)$ (Table 5 , Figure $\left.8 \mathrm{a}\right)$. The presence of three AlOHAl stretching bands is explained by the various $\mathrm{Si} / \mathrm{Al}$ configurations in the vicinity of the $\mathrm{OH}$-sharing Al-octahedra $[17,20]$. The number and actual positions of these bands can be also affected by $\mathrm{Mg}$ for $\mathrm{Al}$ substitutions in the adjacent octahedra, as well as by the nearest interlayer site being occupied or vacant [61]. The positions of the three AlOHAl stretching bands of the mica structure of sample RM30 are similar to those reported for synthetic muscovite $(3659,3644$ and $3629 \mathrm{~cm}^{-1}$ ) [81]. In illite samples with the $\mathrm{Mg}$ contents of $\sim 0.4$ cations p.h.f.u., the maximum is either at $3606 \mathrm{~cm}^{-1}$, determined by the AlOHMg vibration (samples 60 and 60/3, Table 3), or at $3617 \mathrm{~cm}^{-1}$ resulting from the superposition of AlOHMg $\left(3603 \mathrm{~cm}^{-1}\right)$ and AlOHAl $\left(3620 \mathrm{~cm}^{-1}\right)$ (sample IWi-1, Table 5, Figure $8 \mathrm{~b}$ ). The other vibrations contributing to the broad $\mathrm{OH}$-stretching band of $\mathrm{Mg}$-rich illite IWi-1 include MgOHFe ${ }^{3+}\left(3566 \mathrm{~cm}^{-1}\right)$, AlOHAl $\left(3640 \mathrm{~cm}^{-1}\right)$ and the AlOHFe ${ }^{3+}\left(3656 \mathrm{~cm}^{-1}\right)$ and AlOHAl bands $\left(3672 \mathrm{~cm}^{-1}\right)$ of the pyrophyllite-like component (Figure $8 \mathrm{~b}$, Table 5). The position of the pyrophyllite-like $\mathrm{AlOHFe}{ }^{3+}$ band is somewhat higher than observed by Farmer [12] and Lantenois et al. [80] (3647 and $3645 \mathrm{~cm}^{-1}$, respectively) but close to that reported by Besson and Drits [17,18] $\left(3651-3654 \mathrm{~cm}^{-1}\right)$. 

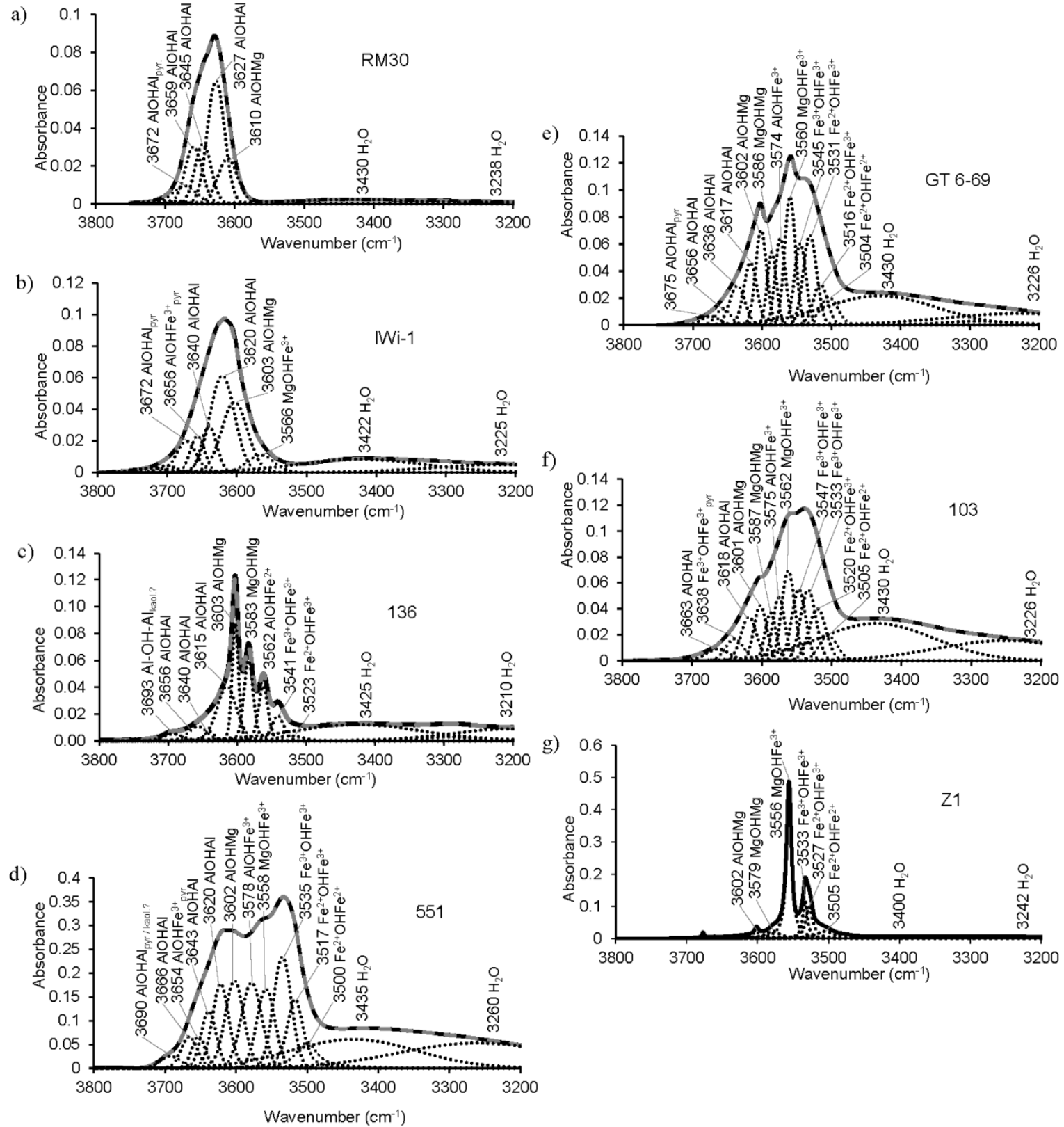

Figure 8. Decomposition and curve-fitting of the FTIR spectra of selected samples in the $\mathrm{OH}$-stretching region: (a)—RM30; (b)—IWi-1; (c)—136; (d)—551; (e)—GT6-69; (f)—103; (g)—Z1.

The $\mathrm{OH}$-stretching region of the aluminoceladonite spectra differs dramatically from that of illites. The spectra of samples 136 (Figures 1 and 8c) and Z2 (not shown) consist of several sharp and well-resolved peaks, the most intense at $3603 \mathrm{~cm}^{-1}(\mathrm{AlOHMg})$, and $\mathrm{MgOHMg}, \mathrm{AlOHFe}^{2+}$ and $\mathrm{Fe}^{3+} \mathrm{OHFe}^{3+}$ at $3583,3559-3562$ and $3538-3540 \mathrm{~cm}^{-1}$, respectively (Table 3). In addition, AlOHAl (3615, 3640 and $\left.3656 \mathrm{~cm}^{-1}\right)$ and $\mathrm{Fe}^{2+} \mathrm{OHFe}^{3+}\left(3523 \mathrm{~cm}^{-1}\right)$ bands are revealed by spectrum decomposition and curve-fitting (Figure 8c). In the other aluminoceladonites, the $\mathrm{OH}$-stretching region contains a wide absorption band with one sharp maximum at $3601-3606 \mathrm{~cm}^{-1}$ and poorly resolved bands that can be identified from decomposition and curve-fitting (e.g., sample 602-1, Figure 1, Table 5). As shown by Besson et al. [82], the resolution of the $\mathrm{OH}$-stretching spectral region of dioctahedral 2:1 phyllosilicates, and aluminoceladonite in particular, is associated with the degree of the order-disorder in the octahedral cation distribution. The typical feature of the aluminoceladonite spectra is therefore the sharp maximum at $\sim 3600 \mathrm{~cm}^{-1}$, which corresponds to the AlOHMg stretching vibration. Another 
characteristic feature is the presence of the $\mathrm{MgOHMg}$ absorption band at $3583-3585 \mathrm{~cm}^{-1}$, which can be identified either by visual inspection or, in the poorly resolved spectra, in the second derivative.

The FTIR spectra of Fe-illites and Al-glauconites in the $\mathrm{OH}$-stretching region differ dramatically from those of illites and, in particular, Fe-bearing Mg-rich illites, as they contain two well-resolved broad bands (Figure 1): one, a superposition of individual vibrations that involve Fe and $\mathrm{Mg}$, with the maximum corresponding to the $\mathrm{Fe}^{3+} \mathrm{OHFe}^{3+}$ band $\left(3532 \pm 4 \mathrm{~cm}^{-1}\right)$, and another, resulting from vibrations involving $\mathrm{Al}$ and $\mathrm{Mg}$, with the maximum corresponding to either $\mathrm{AlOHMg}$ at $3605 \pm 5 \mathrm{~cm}^{-1}$ (most samples) or AlOHAl $\left(3624 \mathrm{~cm}^{-1}\right.$, sample 553/1), or a superposition of the AlOHMg and AlOHAl bands $\left(3614 \mathrm{~cm}^{-1}\right.$, samples 560/3, 551) (Table 3). For $K_{A l} \geq 0.6$, the "Al, $\mathrm{Mg}^{\prime \prime}$ band is either stronger than or of similar intensity as the "Fe" band (e.g., sample BSH11, Figure 1); for $K_{A l} \sim 0.5$, the "Fe" band is stronger (sample 551, Figures 1 and $8 \mathrm{~d}$ ). The "Fe" band of Al-glauconite 551 is a superposition of the following individual vibrations: $\mathrm{Fe}^{2+} \mathrm{OHFe}^{2+}\left(3500 \mathrm{~cm}^{-1}\right), \mathrm{Fe}^{2+} \mathrm{OHFe}^{3+}\left(3517 \mathrm{~cm}^{-1}\right), \mathrm{Fe}^{3+} \mathrm{OHFe}^{3+}$ $\left(3535 \mathrm{~cm}^{-1}\right), \mathrm{MgOHFe}^{3+}\left(3558 \mathrm{~cm}^{-1}\right)$ and $\mathrm{AlOHFe}{ }^{3+}\left(3578 \mathrm{~cm}^{-1}\right)$, while the "Al, $\mathrm{Mg}^{\prime}$ ' band involves $\operatorname{AlOHMg}\left(3602 \mathrm{~cm}^{-1}\right)$ and AlOHAl $\left(3620 \mathrm{~cm}^{-1}, 3643 \mathrm{~cm}^{-1}\right.$ and $\left.3666 \mathrm{~cm}^{-1}\right)$ modes, as well as AlOHFe band of the pyrophyllite-like component at $3654 \mathrm{~cm}^{-1}$; the band at $3690 \mathrm{~cm}^{-1}$ refers to the AlOHAl of either a pyrophyllite-like component or a minor kaolin admixture (Figure 8d, Table 5). The individual

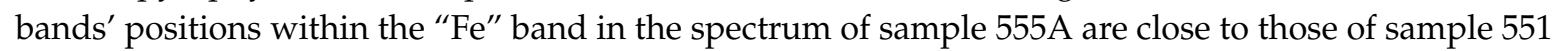
but the intensity distribution is different; the band positions and intensity distribution in the " $\mathrm{Al}, \mathrm{Mg}$ " region are similar to those in sample 551 but for the presence of the $\mathrm{MgOHMg}$ band at $3587 \mathrm{~cm}^{-1}$ and lower intensity of the $\mathrm{AlOHFe}^{3+}$ band (Table 5).

The OH-stretching vibration regions of glauconites, with few exceptions, show worse resolution, as compared to Al-glauconites. The distinguishing feature of glauconite spectra is the presence of maxima at 3533-3538 $\mathrm{cm}^{-1}$ and $~ 3550-3560 \mathrm{~cm}^{-1}$ (corresponding to $\mathrm{Fe}^{3+} \mathrm{OHFe}^{3+}$ and $\mathrm{Fe}^{3+} \mathrm{OHMg}$, respectively), which can be either well- or poorly resolved (from sharp bands to shoulders) and have similar or different intensities (Figure 1, Table 3). For example, the $\mathrm{OH}$-stretching region of sample 103 is a broad band with two poorly resolved maxima at $\sim 3530$ and $\sim 3560 \mathrm{~cm}^{-1}$, and a shoulder at $\sim 3600 \mathrm{~cm}^{-1}$ (corresponding to AlOHMg), whereas sample GT6-69 shows sharp bands at 3560 and $3602 \mathrm{~cm}^{-1}$, and a broad but distinct shoulder at $\sim 3530 \mathrm{~cm}^{-1}$ (Figure 1). The spectrum decomposition and curve-fitting revealed similar types of individual cation-OH-cation bands at close positions with similar, albeit not identical, intensity distributions (Figure 8e,f, Table 5). There are, however, a few differences. The spectrum of sample GT6-69, which has more Al and less Fe $\left(K_{A l}=0.38\right)$, shows three AlOHAl bands $\left(3617,3636\right.$ and $\left.3656 \mathrm{~cm}^{-1}\right)$ and a pyrophyllite-like AlOHAl band at $3675 \mathrm{~cm}^{-1}$, whereas in that of sample $103\left(K_{A l}=0.24\right)$ there are two AlOHAl bands $\left(3618\right.$ and $\left.3663 \mathrm{~cm}^{-1}\right)$. In sample 103, the band at $3638 \mathrm{~cm}^{-1}$ is identified as the $\mathrm{Fe}^{3+} \mathrm{OHFe}^{3+}$ band of the ferripyrophyllite-like structure fragments, as it is only this assignment that provides good agreement between the cation composition obtained from the FTIR data and that given by the crystal-chemical formula (Table 6). Although Besson and Drits [18] only found two AlOHAl bands in the $\mathrm{OH}$-stretching regions of glauconites, the presence of three AlOHAl bands in the spectrum of sample GT6-69 may be associated with the highly heterogeneous cation composition, which, as shown by Drits et al. [9] can be realized as phase heterogeneity at micro- and nano-levels. The third AlOHAl band may therefore refer to Al-rich microor nanocrystals within the sample.

Unlike the glauconites studied by Besson and Drits $[17,18]$ both samples 103 and GT6-69, as well as sample 37/71 A (Table 5), display two $\mathrm{Fe}^{3+} \mathrm{OHFe}^{3+}$ bands at $3531-3533 \mathrm{~cm}^{-1}$ and $3545-3547 \mathrm{~cm}^{-1}$ of similar intensity, and no spectra decomposition in terms of a single $\mathrm{Fe}^{3+} \mathrm{OHFe}^{3+}$ band would lead to a good cation composition fit. The presence of two $\mathrm{Fe}^{3+} \mathrm{OHFe}^{3+}$ bands in micas with high Fe content in combination with complex tetrahedral and octahedral cation compositions may be associated with the heterogeneity in the local environments around the vibrating $\mathrm{OH}$ group. The total amounts of Fe cations obtained from the FTIR data are nearly identical to those in the crystal-chemical formulae for both samples 103 and GT6-69 (Table 6). For sample GT6-69, the oxidation state of Fe was not determined and all Fe was assumed to be trivalent [52]; the FTIR data, however, indicate the presence 
of $0.18 \mathrm{Fe}^{2+}$ cations p.h.f.u. The ratio $\mathrm{Fe}^{3+} / \mathrm{Fe}^{2+}$ in sample 103 was assumed to be similar to that of sample 3771 based on a similar geological setting and overall cation composition [8]; according to the FTIR data, the actual content of $\mathrm{Fe}^{2+}$ should be higher than that in the crystal-chemical formula $(0.23$ vs. 011 cations p.h.f.u.) (Table 6).

The $\mathrm{OH}$-stretching regions of celadonites differ dramatically from those of all the other Fe-bearing mica varieties (Figures 1 and 8g). They show two sharp, well-resolved maxima, the stronger at 3555-3556 $\mathrm{cm}^{-1}\left(\mathrm{Fe}^{3+} \mathrm{OHMg}\right)$ and a less intense one at $3532-3533 \mathrm{~cm}^{-1}\left(\mathrm{Fe}^{3+} \mathrm{OHFe}^{3+}\right)$. The AlOHMg stretching mode may appear as a minor sharp band (samples TAIH, not shown, and Z1, Figures 1 and 8g). As in the case of aluminoceladonites, the high resolution of the $\mathrm{OH}$-stretching spectral region of celadonites is associated with the high degree of ordering in the octahedral cation distribution [82]. In addition to the sharp $\mathrm{MgOHFe}^{3+}$ and $\mathrm{Fe}^{3+} \mathrm{OHFe}^{3+}$ bands, the spectrum decomposition and curve-fitting of celadonite $\mathrm{Z} 1$ reveals the presence of the $\mathrm{Fe}^{2+} \mathrm{OHFe}^{2+}$ band $\left(3505 \mathrm{~cm}^{-1}\right)$, the $\mathrm{Fe}^{2+} \mathrm{OHFe}^{3+}$ band $\left(3527 \mathrm{~cm}^{-1}\right)$, and the $\mathrm{MgOHMg}$ band at $3579 \mathrm{~cm}^{-1}$ (Figure $8 \mathrm{~g}$, Table 5). The band positions and intensity distribution in this decomposition are in agreement with those of $[17,18]$ for sample $Z 1$, except that the weak $\mathrm{MgOHFe}^{2+}\left(3542 \mathrm{~cm}^{-1}\right), \mathrm{AlOH} \mathrm{Fe}{ }^{3+}\left(3574 \mathrm{~cm}^{-1}\right)$ and AlOHAl $\left(3621 \mathrm{~cm}^{-1}\right)$ bands reported by $[17,18]$ were not found in this work. These minor discrepancies may be associated with the fact that different specimens of the same sample were used in the two studies in question.

On the whole, the results of the $\mathrm{OH}$-stretching region decomposition and curve-fitting are in accordance with the interpretation and band assignments of $[17,18]$. The few differences include the presence of a second $\mathrm{Fe}^{3+} \mathrm{OHFe}^{3+}$ band and a third $\mathrm{AlOHAl}$ band in some glauconites with a high $\mathrm{Fe}$ content and highly heterogeneous cation composition, as well as slightly wider ranges of band position variations for specific cation-OH-cation vibration modes (Table 5).

\section{Conclusions}

The approach suggested for the interpretation of the FTIR spectroscopy data involves relationships between band positions and cation composition, and provides a set of distinguishing features and identification criteria for K-dioctahedral $1 M$ micas that include the band positions and profile in the regions of $\mathrm{Si}-\mathrm{O}$ bending, $\mathrm{Si}-\mathrm{O}$ stretching and $\mathrm{OH}$-stretching vibrations (Table 7). In particular, FTIR data allow unambiguous identification of illite and aluminoceladonite, which are often confused based on superficial interpretation of XRD data. Specifically, a sharp maximum from the AlOHMg stretching vibration at $\sim 3600 \mathrm{~cm}^{-1}$, the presence of a MgOHMg stretching vibration at 3583-3585 $\mathrm{cm}^{-1}$, as well as characteristic band positions in the Si-O bending $\left(435-439,468-472\right.$ and $\left.509-520 \mathrm{~cm}^{-1}\right)$ and stretching regions (985-1012 and 1090-1112 $\mathrm{cm}^{-1}$ ) are typical of aluminoceladonite. Distinguishing between Mg-poor and Mg-rich illites based solely on FTIR data appears problematic, but the position of the $\mathrm{Si}-\mathrm{O}$ bending modes and the maximum absorption in the region of $\mathrm{OH}$-stretching vibrations may serve as additional criteria. Regression equations relating the band positions in the Si-O bending region with the contents of tetrahedral $\mathrm{Al}$, octahedral $\mathrm{Al}$ and octahedral $\mathrm{Mg}$ allow evaluation of the contents of corresponding cations in illites and aluminoceladonites. According to FTIR characteristics, the Fe-bearing K-dioctahedral $1 M$ micas are divided into 4 groups differing in the value of $K_{A 1}=\mathrm{Al} /(\mathrm{Al}$ ${ }^{\mathrm{VI}} \mathrm{Fe}^{3+}$ ), where $\mathrm{Al}$ and ${ }^{\mathrm{VI}} \mathrm{Fe}^{3+}$ are the amounts of $\mathrm{Al}$ and $\mathrm{Fe}^{3+}$ octahedral cations p.h.f.u.: Fe-bearing Mg-rich illites $\left(K_{A l} \sim 0.9\right)$; Fe-illites $\left(0.65 \leq K_{A 1} \leq 0.75\right) /$ Al-glauconites $\left(0.5 \leq K_{A l} \leq 0.6\right)$, with Al-glauconites having $K_{A l} \sim 0.5$ forming a special subgroup; glauconites $\left(K_{A l}<0.5\right)$; and celadonites $\left(K_{A l}<0.2\right)($ Table 7$)$. 
Table 7. FTIR distinctive features for K-dioctahedral $1 M$ micas (see text for details and explanation).

\begin{tabular}{|c|c|c|c|c|c|c|c|}
\hline & $\begin{array}{l}\text { Si-O Bend } \\
\left(\delta_{1}, \mathrm{~cm}^{-1}\right)\end{array}$ & $\begin{array}{l}\text { Si-O-Si Bend } \\
\left(\delta_{2}, \mathrm{~cm}^{-1}\right)\end{array}$ & $\begin{array}{l}\text { Si-O-Al Bend } \\
\left(\delta_{3}, \mathrm{~cm}^{-1}\right)\end{array}$ & $\begin{array}{l}\text { Si-O-Fe Bend } \\
\left(\delta_{3}, \mathrm{~cm}^{-1}\right)\end{array}$ & $\begin{array}{l}\text { Si-O Stretch } \\
\left(\mathrm{cm}^{-1}\right)\end{array}$ & $\begin{array}{c}\text { Si-O } \\
\text { apical Stretch } \\
\left(\mathrm{cm}^{-1}\right)\end{array}$ & OH Stretch \\
\hline \multicolumn{8}{|c|}{ Fe-poor, K-dioctahedral micas $\left(\mathrm{Fe}_{\text {tot }} \leq 0.3\right.$ cations $\left.p . h . f . u\right)$} \\
\hline$(\mathrm{Mg}, \mathrm{Fe})$-poor illites & $414-425$ & $471-477$ & $525-535$ & - & $1023-1027$ & $\begin{array}{l}1070-1080 \\
\text { (shoulder) }\end{array}$ & Broad band, maximum at $\sim 3625-3630 \mathrm{~cm}^{-1}$ \\
\hline Mg-rich illites & $419-435$ & $\sim 470$ & $519-525$ & - & $1008-1021$ & $1075-1090$ & Broad band, maximum at $\sim 3605-3620 \mathrm{~cm}^{-1}$ \\
\hline Aluminoceladonites & $435-439$ & $\sim 470$ & $509-520$ & - & 985-1012 & $1090-1112$ & $\begin{array}{l}\text { Sharp bands at } \sim 3600 \mathrm{~cm}^{-1}(\mathrm{AlOHMg} \text {, strongest); } 3583 \\
\mathrm{cm}^{-1}(\mathrm{MgOHMg}) ; \sim 3560 \mathrm{~cm}^{-1} \text { (AlOHFe } \\
\text { MgOHFe }{ }^{3+} \text { ); } \sim 3540 \mathrm{~cm}^{-1} \text { (FeOHFe); } \\
\text { OR broad band with a sharp maximum at } \sim 3600 \mathrm{~cm}^{-1}\end{array}$ \\
\hline \multicolumn{8}{|c|}{ Fe-bearing, K-dioctahedral micas ( $\mathrm{Fe}_{\text {tot }} \geq 0.3$ cations p.h.f.u) } \\
\hline $\begin{array}{l}\text { Fe-bearing Mg-rich illites } \\
\left(K_{A l} \sim 0.9\right)\end{array}$ & \multirow{5}{*}{$434-440$} & $\sim 470$ & $\sim 520$ & - & $\sim 1010$ & 1084-1089 & Broad band, maximum at $3600-3610 \mathrm{~cm}^{-1}$ \\
\hline $\begin{array}{c}\text { Fe illites }\left(0.65 \leq K_{A l} \leq 0.75\right) \\
\text { Al-glauconites }\left(0.5<K_{A l}\right. \\
\leq 0.6)\end{array}$ & & $\begin{array}{c}467-471 ; \\
450-455\left({ }^{*} \text { or sh) }\right.\end{array}$ & $514-526$ & $484-496$ & 987-1017 & $\begin{array}{l}1072-1101 \text { (band } \\
\text { or shoulder) }\end{array}$ & $\begin{array}{c}\text { Two bands, } 3528-3534\left(\text { ("Fe") and } 3600-3610 \mathrm{~cm}^{-1} \text { ("Al, }\right. \\
\text { Mg"). Similar intensity } \\
\text { or "Al, Mg" band stronger }\end{array}$ \\
\hline Al-glauconites $\left(K_{A l} \sim 0.5\right)$ & & $\begin{array}{l}465-469 ; \\
454-455\end{array}$ & $514-518$ (sh) & 486 (sh) & & & "Fe" band stronger \\
\hline Glauconites $\left(K_{A l}<0.5\right)$ & & \multirow[b]{2}{*}{$453-463$} & - & \multirow[b]{2}{*}{$483-499$} & & & $\begin{array}{c}\text { Bands at } 3533-3538 \mathrm{~cm}^{-1} \text { and } \sim 3550-3560 \mathrm{~cm}^{-1}, \\
\text { variable resolution and relative intensity }\end{array}$ \\
\hline Celadonites $\left(K_{A l}<0.2\right)$ & & & & & $\begin{array}{l}\text { (957), } 975-978 \\
\text { (sharp) }\end{array}$ & $\begin{array}{l}1090 \text { or } 1072-1074 \\
\text { (sharp), } 1100-1113 \\
\text { (sharp band or } \\
\text { shoulder) }\end{array}$ & $\begin{array}{l}\text { Sharp, well-resolved bands at } 3556 \mathrm{~cm}^{-1}\left(\mathrm{MgOHFe}^{3+}\right) \\
\text { and } 3532-3533 \mathrm{~cm}^{-1}\left(\mathrm{Fe}^{3+} \mathrm{OHFe}^{3+}\right)\end{array}$ \\
\hline
\end{tabular}


The band positions and profiles in the regions of $\mathrm{Si}-\mathrm{O}$ bending, $\mathrm{Si}-\mathrm{O}$ stretching and, most importantly, $\mathrm{OH}$-stretching vibrations allow not only unambiguous identification of illites, aluminoceladonites and celadonites, but also distinction between Fe-illites and illites proper, as well as between Al-glauconites and glauconites. On the other hand, distinction between Fe-illites and Al-glauconites, which have similar FTIR features, requires data on cation composition and unit-cell parameters.

The 950-600 $\mathrm{cm}^{-1}$ region is less informative from the point of view of identification because of partial overlap and coupling of the various bands, as well as ambiguities in band assignments. In combination with the data on the $\mathrm{Si}-\mathrm{O}$ bending and stretching modes, as well as the OH-stretching vibrations, the band positions in this region may, however, provide helpful additional information.

The band positions and profiles in the $\mathrm{OH}$-stretching regions, especially for Fe-bearing $\mathrm{K}$-dioctahedral micas, can serve as additional diagnostic criteria for phase heterogeneity realized at the micro- and nano-levels. The validity of the decomposition and curve-fitting of $\mathrm{OH}$-stretching regions was confirmed by the good agreement between cation compositions obtained from FTIR data and those provided by the crystal-chemical formulae for a representative collection of samples in terms of a unique set of individual $\mathrm{OH}$ band positions that vary within narrow wavenumber intervals. For monomineralic samples with known cation compositions, the proportions of various types of cation-OH-cation configurations obtained from the decomposition of the $\mathrm{OH}$-stretching regions, in combination of the data of other methods, such as Mössbauer and NMR spectroscopies, can be used to reconstruct the two-dimensional octahedral cation distribution [82-84] and thus reveal the mechanisms for structural transformations (e.g., release of $\mathrm{Mg}$ and Fe during diagenetic transformations of illite-smectites into illite-tobelite smectites) [83]. Further research is needed to find out to what extent the $\mathrm{Al}$ and $\mathrm{Mg}$ cation contents obtained from the data on $\mathrm{Si}-\mathrm{O}$ bending band positions may be used for the interpretation of $\mathrm{OH}$-stretching vibration regions of $\mathrm{Al}$-rich, $(\mathrm{Mg}, \mathrm{Fe})$-poor micas in the absence of chemical analysis data.

Supplementary Materials: The following are available online at http://www.mdpi.com/2075-163X/10/2/153/s1, Figure S1: FTIR spectra of K- dioctahedral $1 M$ micas, Table S1: Parameters of IR spectra decomposition.

Author Contributions: All authors have read and agreed to the published version of the manuscript. B.B.Z. is responsible for investigation, methodology and writing - original draft preparation. V.A.D. is responsible for conceptualization, data curation, investigation, methodology, supervision and writing-review and editing. O.V.D. is responsible for investigation and visualization.

Funding: The authors acknowledge the financial support of the budget project \#0135-2016-0010. The development and application of methodical approaches for sample treatment and preparation for FTIR investigation of 2:1 layered phyllosilicates was financially supported by the Russian Science Foundation (Project \#16-17-10270).

Acknowledgments: The authors are grateful to Tatiana A. Ivanovskaya, Douglas McCarty, and Jan Środoń for providing some of the samples. Thanks are due to the anonymous reviewers for valuable comments.

Conflicts of Interest: The authors declare no conflict of interest. The funders had no role in the design of the study; in the collection, analyses, or interpretation of data; in the writing of the manuscript, or in the decision to publish the results.

\section{References}

1. Środoń, J.; Eberl, D.D. Illite. In Micas: Reviews in Mineralogy; Bailey, S.W., Ed.; Mineralogical Society of America: Washington, DC, USA, 1984; Volume 13, pp. 495-544.

2. Drits, V.A.; Kossovskaya, A.G. Clay Minerals: Micas and Chlorites; Nauka: Moscow, Russia, 1991 ; p. 175. (In Russian)

3. Brigatti, M.F.; Guggenheim, S. Mica crystal chemistry and the influence of pressure, temperature and solid solution on atomistic models. In Micas: Crystal Chemistry and Metamorphic Petrology. Reviews in Mineralogy and Geochemistry; Mottana, A., Sassi, F.E., Thompson, J.B., Jr., Guggenheim, S., Eds.; Mineralogical Society of America: Washington, DC, USA; Accademia Nazionale dei Lincei: Roma, Italy, 2002; Volume 46, Chapter 1; pp. 1-97. 
4. Drits, V.A.; McCarty, D.K.; Zviagina, B.B. Crystal-chemical factors responsible for the distribution of octahedral cations over trans- and cis-sites in dioctahedral 2:1 layer silicates. Clays Clay Miner. 2006, 54, 131-153. [CrossRef]

5. Drits, V.A.; Zviagina, B.B.; McCarty, D.K.; Salyn, A.L. Factors responsible for crystal-chemical variations in the solid solutions from illite to aluminoceladonite and from glauconite to celadonite. Am. Miner. 2010, 95, 348-361. [CrossRef]

6. Wilson, M.D. Rock-Forming Minerals, Volume 3C, Sheet Silicates: Clay Minerals; The Geological Society: London, UK, 2013.

7. Zviagina, B.B.; Drits, V.A.; Środoń, J.; McCarty, D.K.; Dorzhieva, O.V. The illite-aluminoceladonite series: Distinguishing features and identification criteria from X-ray diffraction and infrared spectroscopy data. Clays Clay Miner. 2015, 63, 378-394. [CrossRef]

8. Zviagina, B.B.; Drits, V.A.; Sakharov, B.A.; Ivanovskaya, T.A.; Dorzhieva, O.V. Crystal-chemical regularities and identification criteria in Fe-bearing, K-dioctahedral $1 M$ micas from X-ray diffraction and infrared spectroscopy data. Clays Clay Miner. 2017, 65, 234-251. [CrossRef]

9. Drits, V.A.; Sakharov, B.A.; Ivanovskaya, T.A.; Pokrovskaya, E.V. Crystal-chemical microheterogeneity of Precambrian globular dioctahedral mica minerals. Lithol. Miner. Resour. 2013, 48, 503-528. [CrossRef]

10. Farmer, C.V.; Russell, J.D. The infra-red spectra of layer silicates. Spectrochim. Acta 1964, 20, 1140-1173. [CrossRef]

11. Farmer, V.C. The characterization of adsorption bonds in clays by infrared spectroscopy. Soil Sci. 1971, 112, 62-68. [CrossRef]

12. Farmer, V.C. The layer silicates. In Infrared Spectra of Minerals, Monograph 4; Farmer, V.C., Ed.; Mineralogical Society: London, UK, 1974; Chapter 15; pp. 331-363.

13. Slonimskaya, M.V.; Besson, G.; Dainyak, L.G.; Tchoubar, C.; Drits, V.A. Interpretation of the IR spectra of celadonites and glauconites in the region of $\mathrm{OH}$-stretching frequencies. Clay Miner. 1986, 21, 377-388. [CrossRef]

14. Velde, B. Infrared spectra of synthetic micas in the series muscovite-MgAl celadonite. Am. Miner. 1978, 63, 343-349.

15. Velde, B. Clay Minerals: A Physico-Chemical Explanation of Their Occurrence. Developments in Sedimentology; Elsevier: Amsterdam, The Netherlands, 1985; Volume 40.

16. Russell, J.D.; Fraser, A.R. Infrared methods. In Clay Mineralogy: Spectroscopic and Chemical Determinative Methods; Wilson, M.J., Ed.; Chapman \& Hall: London, UK, 1994; pp. 11-67.

17. Besson, G.; Drits, V.A. Refined relationships between chemical composition of dioctahedral fine-dispersed mica minerals and their infrared spectra in the $\mathrm{OH}$ stretching region. Part I. Identification of the $\mathrm{OH}$ stretching bands. Clays Clay Miner. 1997, 45, 158-169. [CrossRef]

18. Besson, G.; Drits, V.A. Refined relationship between chemical composition of dioctahedral fine-dispersed mica minerals and their infrared spectra in the $\mathrm{OH}$ stretching region. Part II. The main factors affecting $\mathrm{OH}$ vibration and quantitative analysis. Clays Clay Miner. 1997, 45, 170-183. [CrossRef]

19. Kloprogge, J.T.; Frost, R.L.; Hickey, L. Infrared absorption and emission study of synthetic mica-montmorillonite in comparison to rectorite, beidellite and paragonite. J. Mater. Sci. Lett. 1999, 18, 1921-1923. [CrossRef]

20. Beran, A. Infrared spectroscopy of micas. In Micas: Crystal Chemistry and Metamorphic Petrology, Reviews in Mineralogy and Geochemistry; Mottana, A., Sassi, F.P., Thomson, J.B., Jr., Guggenheim, S., Eds.; Mineralogical Society of America: Washington, DC, USA; Accademia Nazionale dei Lincei: Roma, Italy, 2002; Volume 46, pp. 351-369.

21. Post, J.L.; Borer, L. Physical properties of selected illites, beidellites and mixed-layer illite-beidellites from southwestern Idaho, and their infrared spectra. Appl. Clay Sci. 2002, 22, 77-91. [CrossRef]

22. Madejová, J. FTIR techniques in clay mineral studies. Vib. Spectrosc. 2003, 31, 1-10. [CrossRef]

23. Weiszburg, T.; Tóth, E.; Beran, A. Celadonite, the 10-Å green clay mineral of the manganese carbonate ore, Úrkút, Hungary. Acta Miner. Petrogr. 2004, 45, 65-80.

24. Heller-Kallai, L.; Lapides, I. Dehydroxylation of muscovite: Study of quenched samples. Phys. Chem. Miner. 2015, 42, 835-845. [CrossRef]

25. Singh, M.; Singh, L. Vibrational spectroscopic study of muscovite and biotite layered phyllosilicates. Indian J. Pure Appl. Phys. 2016, 54, 116-122. 
26. Madejová, J.; Gates, W.P.; Petit, S. IR spectra of clay minerals. In Infrared and Raman Spectroscopies of Clay Minerals; Gates, W.P., Klopprogge, J.T., Madejová, J., Bergaya, F., Eds.; Elsevier: Amsterdam, The Netherlands, 2017; Chapter 5; Volume 8, pp. 107-149.

27. LeGras, M.; Laukamp, C.; Lau, I.; Mason, P. NVCL Spectral Reference Library_Phyllosilicates Part 2: Micas; CSIRO: Canberra, Australia, 2018.

28. Mathian, M.; Hebert, B.; Baron, F.; Petit, S.; Lescuyer, J.-L.; Furic, R.; Beaufort, D. Identifying the phyllosilicate minerals of hypogene ore deposits in lateritic saprolites using the near-IR spectroscopy second derivative methodology. J. Geochem. Explor. 2018, 186, 298-314. [CrossRef]

29. Ross, P.-S.; Bourke, A.; Schnitzler, N.; Conly, A. Exploration Vectors from Near Infrared Spectrometry near the McLeod Volcanogenic Massive Sulfide Deposit, Matagami District, Québec. Econ. Geol. 2019, 114, 613-638. [CrossRef]

30. Shishelova, T.I.; Lipovchenko, E.L.; Shulga, V.V. Mica Dehydroxylation Mechanism. J. Appl. Spectr. 2019, 86, 817-821. [CrossRef]

31. Grandjean, G.; Briottet, X.; Adeline, K.; Bourguignon, A.; Hohmann, A. Clay Minerals Mapping from Imaging Spectroscopy. In Geospatial Analyses of Earth Observation (EO) Data; Pepe, A., Ed.; IntechOpen: London, UK, 2019. [CrossRef]

32. Della Ventura, G.; Hawthorne, F.C.; Iezzi, G. Synthesis and solid solution in "rubidium richterite", $\mathrm{Rb}(\mathrm{NaCa}) \mathrm{Mg}_{5} \mathrm{Si}_{8} \mathrm{O}_{22}(\mathrm{OH}, \mathrm{F})_{2}$. Phys. Chem. Miner. 2019, 46, 759-770. [CrossRef]

33. Yang, M.; Han, L.; Xu, Y.; Ke, H.; Zhou, N.; Dong, H.; Liu, S.; Qiao, G. Near Infrared Spectroscopic Study of Trioctahedral Chlorites and Its Remote Sensing Application. Open Geosci. 2019, 11, 815-828. [CrossRef]

34. Eberl, D.D.; Środoń, J.; Lee, M.; Nadeau, P.H.; Northrop, H.R. Sericite from the Silverton Caldera, Colorado: Correlation among structure, composition, origin, and particle thickness. Am. Miner. 1987, 72, 914-934.

35. Viczián, I. Hungarian investigations on the "Zempleni" illite. Clays Clay Miner. 1997, 45, 114-115. [CrossRef]

36. Środoń, J.; Zeelmaekers, E.; Derkowski, A. The charge of component layers of illite-smectite in bentonites and the nature of end-member illite. Clays Clay Miner. 2009, 57, 649-671. [CrossRef]

37. Środoń, J.; Clauer, N.; Huff, W.; Dudek, T.; Banaś, M. K-Ar dating of the Lower Palaeozoic K-bentonites from the Baltic Basin and the Baltic Shield: Implications for the role of temperature and time in the illitization of smectite. Clay Miner. 2009, 44, 361-387. [CrossRef]

38. Grathoff, G.H.; Moore, D.M.; Kluessendorf, J.; Mikulic, D.G. The Waukesha illite, a Silurian Residuum from Karstification, Proposed as a Candidate for the Source Clay Repository. Program with abstracts. In Proceedings of the 32nd Annual Clay Minerals Society Meeting, Baltimore, MD, USA, 3-8 June 1995; p. 54.

39. Ivanovskaya, T.A.; Tsipursky, S.I.; Yakovleva, O.V. Mineralogy of globular glauconites from Vendian and Riphean of the Ural and Siberia. Litologia i Poleznye Iskopaemye 1989, 3, 83-99. (In Russian)

40. Seifert, F. X-ray powder data for Mg-A1-celadonite (leucophyllite) from Barcza, Poland. Contrib. Miner. Petrol. 1968, 19, 93-96. [CrossRef]

41. Kardymowicz, I. O seladonicie z Barczy w Górach Swietokrzyskich. Geol. Quart. 1960, 4, 609-618. (In Polish)

42. Sokolova, T.N.; Drits, V.A.; Sokolova, A.L.; Stepanov, S.S. Structural and mineralogical characteristics and conditions of formation of leucophyllite from salt-bearing deposits of Inder. Litologia i Poleznye Iskopaemye 1976, 6, 80-95. (In Russian)

43. Środoń, J.; Paszkowski, M.; Drygant, D.; Anczkiewicz, A.; Banas, M. Thermal history of Lower Paleozoic rocks on the Peri-Tornquist margin of the East European Craton (Podolia, Ukraine) inferred from combined XRD, K-Ar, and AFT data. Clays Clay Miner. 2013, 61, 107-132. [CrossRef]

44. Petrova, V.V.; Amarjargal, P. Zeolites of Mongolia; Nauka: Moscow, Russia, 1996; p. 150. (In Russian)

45. Ivanovskaya, T.A.; Kats, A.G.; Florova, Z.B.; Tsipursky, S.I.; Yakovleva, O.V. Structure and lithomineralogical peculiarities of the Basal Lower Riphean in the Olenek Uplift (Osorkhayata Formation), Stratigrafiya. Geologicheskaya Korrelyatsiya 1993, 1, 84-92. (In Russian)

46. Ivanovskaya, T.A. Globular glauconite-illite layer silicates in Middle Riphean Debengdinsk Formation of the Olenek Uplift. Lithol. Miner. Resour. 1994, 29, 595-605.

47. Zaitseva, T.S.; Gorokhov, I.M.; Ivanovskaya, T.A.; Semikhatov, M.A.; Kuznetsov, A.B.; Mel'nikov, N.N.; Arakelyants, M.M.; Yakovleva, O.V. Mössbauer characteristics, mineralogy and isotopic age (Rb-Sr, K-Ar) of Upper Riphean glauconites from the Uk Formation, the southern Urals. Stratigr. Geol. Correl. 2008, 14, 227-247. [CrossRef] 
48. Ivanovskaya, T.A.; Zviagina, B.B.; Sakharov, B.A.; Zaitseva, T.S.; Pokrovskaya, E.V.; Dorzhieva, O.V. Globular layer silicates of the glauconite-illite composition in Upper Proterozoic and Lower Cambrian rocks. Lithol. Miner. Resour. 2015, 50, 452-477. [CrossRef]

49. Ivanovskaya, T.A.; Tsipursky, S.I. First find of globular glauconite in the Lower Riphean, Anabar Uplift. Litologia i Poleznye Iskopaemye 1990, 25, 110-121. (In Russian)

50. Nikolaeva, I.V. Minerals of the Glauconite Group in Sedimentary Formations; Nauka: Novosibirsk, Russia, 1977; p. 319. (In Russian)

51. Drits, V.A.; Kameneva MYu Sakharov, B.A.; Dainyak, L.G.; Smoliar, B.B.; Bookin, A.S.; Salyn, A.L. Problems in Determination of the Actual Crystal Structure of Glauconites and Related Phyllosilicates; Nauka: Novosibirsk, Russia, 1993; p. 198. (In Russian)

52. Thompson, J.R.; Hower, J. The mineralogy of glauconite. Clays Clay Miner. 1975, 23, 289-300. [CrossRef]

53. Murav'ev, V.I. Mineral Parageneses of Glauconiee-Siliceous Formations; Nauka: Moscow, Russia, 1983; p. 208. (In Russian)

54. Kimbara, K.; Shimoda, S. A ferric celadonite in amygdales of dolerite at Taiheizan, Akita prefecture, Japan. Appl. Clay Sci. 1973, 4, 143-150.

55. Lazarenko, E.K.; Pavlishin, V.I. Relationship of celadonite and svitalskite. In Mineralogy of Sedimentary Rocks; Naukova Dumka: Kiev, Ukraine, 1976. (In Russian)

56. Malkova, K.M. On the celadonite of Pobuzhye. In Collected Papers on Mineralogy. Lvov Geol. Soc. 1956, 10, 305-318. (In Russian)

57. Strens, R.G., Jr. The comon chain, ribbon and ring silicates. In Infrared Spectra of Minerals, Monograph 4; Farmer, V.C., Ed.; Mineralogical Society: London, UK, 1974; Chapter 14; pp. 305-330.

58. Chryssikos, G.D.; Gates, W.P. Spectral Manipulation and Introduction to Multivariate Analysis. In Infrared and Raman Spectroscopies of Clay Minerals; Gates, W.P., Klopprogge, J.T., Madejová, J., Bergaya, F., Eds.; Elsevier: Amsterdam, The Netherlands, 2017; Volume 8, Chapter 4; pp. 64-106.

59. Madejová, J.; Komadel, P.; Číčel, B. Infrared study of octahedral site populations in smectites. Clay Miner. 1994, 29, 319-326. [CrossRef]

60. Cuadros, J.; Sainz-Diaz, C.I.; Ramirez, R.; Hernandez-Laguna, A. Analysis of Fe segregation in the octahedral sheet of bentonitic illite-smectite by means of FTIR, 27Al MAS NMR and reverse Monte-Carlo simulations. Am. J. Sci. 1999, 299, 289-308. [CrossRef]

61. Zviagina, B.B.; McCarty, D.K.; Środoń, J.; Drits, V.A. Interpretation of infrared spectra of dioctahedral smectites in the region of OH-stretching vibrations. Clays Clay Miner. 2004, 52, 399-410. [CrossRef]

62. Vantelon, D.; Pelletier, M.; Michot, L.J.; Barres, O.; Thomas, F. Fe, Mg and Al distribution in the octahedral sheet of montmorillonites. An infrared study in the OH-bending region. Clay Miner. 2001, 36, 369-379. [CrossRef]

63. Fialips, C.I.; Huo, D.; Yan, L.; Wu, J.; Stucki, J.W. Effect of Fe oxidation state on the IR spectra of Garfield nontronite. Am. Miner. 2002, 87, 630-641. [CrossRef]

64. Madejová, J.; Komadel, P. Baseline studies of the Clay Minerals Society source clays: Infrared methods. Clays Clay Miner. 2001, 49, 410-432. [CrossRef]

65. Beran, A.; Voll, D.; Schneider, H. IR spectroscopy as a tool for the characterization of ceramic precursor phases. In Spectroscopic Methods in Mineralogy, EMU Notes in Mineralogy; Beran, A., Libowitzky, E., Eds.; Eötvös University Press: Budapest, Hungary, 2004; Volume 6, pp. 189-226.

66. Rothbauer Von, R. Untersuchung eines $2 M_{1}$-muskovits mit neutronenstrahlen. Neues Jahrbuch für Mineralogie Monatshefte 1971, 1971, 143-154.

67. Ivaldi, G.; Ferraris, G.; Curetti, N.; Compagnoni, R. Coexisting $3 T$ and $2 M_{1}$ polytypes in a phengite from Cima Pal (Val Savenca, western Alps): Chemical and polytypic zoning and structural characterization. Eur. J. Miner. 2001, 13, 1025-1034. [CrossRef]

68. Smyth, J.R.; Jacobsen, S.D.; Swope, R.J.; Angel, R.J.; Arlt, T.; Domanik, K.; Holloway, J.R. Crystal structures and compressibilities of synthetic $2 M_{1}$ and $3 T$ phengite micas. Eur. J. Miner. 2000, 12, 955-963. [CrossRef]

69. Lee, J.H.; Guggenheim, S. Single crystal X-ray refinement of pyrophyllite-1Tc. Am. Miner. 1981, 66, 350-357.

70. Zviagina, B.B.; Drits, V.A. Structural regularities in $2 M_{1}$ dioctahedral micas: The structure modeling approach. Am. Miner. 2012, 97, 1939-1954. [CrossRef]

71. Goodman, B.A.; Russell, J.D.; Fraser, A.R. A Mössbauer and I.R. spectroscopy study of the structure of nontronite. Clays Clay Miner. 1976, 24, 53-59. [CrossRef] 
72. Gates, W.P. Infrared spectroscopy and the chemistry of dioctahedral smectites. In The Application of Vibrational Spectroscopy to Clay Minerals and Layered Double Hydroxides, CMS Workshop Lectures; Klopproge, J.T., Ed.; The Clay Mineral Society: Aurora, CO, USA, 2005; pp. 125-168.

73. Gates, W.P. Cation mass-Valence sum (CM-VS) approach to assigning $\mathrm{OH}$-bending bands in dioctahedral smectites. Clays Clay Miner. 2008, 56, 10-22. [CrossRef]

74. Madejová, J.; Komadel, P. Information available from infrared spectra of the fine fraction of bentonites. In The Application of Vibrational Spectroscopy to Clay Minerals and Layered Double Hydroxides, CMS Workshop Lectures, Klopproge, J.T., Ed.; The Clay Mineral Society: Aurora, CO, USA, 2005; pp. 65-98.

75. Martinez-Alonso, S.; Rustad, J.R.; Goetz, A.F.H. Ab initio quantum mechanical modelling of infrared vibrational frequencies of the $\mathrm{OH}$ group in dioctahedral phyllosilicates. Part 1: Methods, results and comparison to experimental data. Am. Miner. 2002, 87, 1215-1223. [CrossRef]

76. Moenke, H.H.W. Silica, the three-dimensional silicates, borosilicates, and beryllium silicates. In Infrared Spectra of Minerals, Monograph 4; Farmer, V.C., Ed.; Mineralogical Society: London, UK, 1974; Chapter 16; pp. 365-380.

77. White, W.B. The carbonate minerals. In Infrared Spectra of Minerals, Monograph 4; Farmer, V.C., Ed.; Mineralogical Society: London, UK, 1974; Chapter 12; pp. 227-284.

78. Ryskin, Y.I. The vibrations of protons in minerals: Hydroxyl, water, and ammonium. In Infrared Spectra of Minerals, Monograph 4; Farmer, V.C., Ed.; Mineralogical Society: London, UK, 1974; Chapter 9; pp. 137-182.

79. Chukhrov, F.V.; Gorshkov, A.I.; Rudnitskaya, E.S.; Berezovskaya, V.V.; Sivtsov, A.V. On vernadite. Izvestiya Akademii Nauk SSR, Seriya Geologicheskaya 1978, 6, 5-19. [CrossRef]

80. Lantenois, S.; Bény, J.-M.; Muller, F.; Champallie, R. Integration of iron in natural and synthetic Al-pyrophyllites: An infrared spectroscopic study. Clay Miner. 2007, 42, 129-143. [CrossRef]

81. Langer, K.; Chatterjee, N.D.; Abraham, K. Infrared studies of some synthetic and natural $2 \mathrm{M} 1$ dioctahedral micas. N. Jb. Miner. Abh. 1981, 142, 91-110.

82. Besson, G.; Drits, V.A.; Dayniak, L.G.; Smoliar, B.B. Analysis of cation distribution in dioctahedral micaceous minerals on the basis of IR spectroscopy data. Clays Clay Miner. 1987, 22, 465-478. [CrossRef]

83. Dainyak, L.G.; Drits, V.A.; Zviagina, B.B.; Lindgreen, H. Cation redistribution in the octahedral sheet during diagenesis of illite-smectites from Jurassic and Cambrian oil source rock shales. Am. Miner. 2006, 91, 589-603. [CrossRef]

84. Dainyak, L.G.; Rusakov, V.S.; Sukhorukov, I.A.; Zviagina, B.B.; Drits, V.A. An improved model for the interpretation of Mössbauer spectra of dioctahedral 2:1 trans-vacant Fe-rich micas: Refinement of parameters. Eur. J. Miner. 2009, 21, 995-1008. [CrossRef] 